\title{
BIMp-Chart-A Global Decision Support System for Measuring BIM Implementation Level in Construction Organizations
}

\author{
Qurratulain Malik ${ }^{1}$, Abdur Rehman Nasir ${ }^{1}$, Rabiah Muhammad ${ }^{1}$, Muhammad Jamaluddin Thaheem ${ }^{2}(\mathbb{D}$, \\ Fahim Ullah ${ }^{3, *} \mathbb{B}$, Khurram Iqbal Ahmad Khan ${ }^{1} \mathbb{D}$ and Muhammad Usman Hassan ${ }^{1}$ \\ 1 Department of Construction Engineering and Management, School of Civil and Environmental \\ Engineering (SCEE), National University of Sciences and Technology (NUST), Islamabad 44000, Pakistan; \\ qurratulainmalik@nit.nust.edu.pk (Q.M.); abdur.nasir@nit.nust.edu.pk (A.R.N.); \\ rabiahmuhammad@nit.nust.edu.pk (R.M.); khurramiqbal@nit.nust.edu.pk (K.I.A.K.); \\ usman.hassan@nice.nust.edu.pk (M.U.H.) \\ 2 Geelong Waterfront Campus, School of Architecture and Built Environment, Locked Bag 20001, \\ Deakin University, Geelong, VIC 3220, Australia; jamal.thaheem@deakin.edu.au \\ 3 School of Civil Engineering and Surveying, University of Southern Queensland, \\ Springfield, QLD 4300, Australia \\ * Correspondence: fahim.ullah@usq.edu.au
}

Citation: Malik, Q.; Nasir, A.R.; Muhammad, R.; Thaheem, M.J.; Ullah, F.; Khan, K.I.A.; Hassan, M.U. BIMp-Chart-A Global Decision Support System for Measuring BIM Implementation Level in Construction Organizations. Sustainability 2021, 13, 9270. https:// doi.org/10.3390/su13169270

Academic Editors: Ana

Blanco Álvarez, Francesc Pardo Bosch and Pablo Pujadas Álvarez

Received: 18 June 2021

Accepted: 17 August 2021

Published: 18 August 2021

Publisher's Note: MDPI stays neutral with regard to jurisdictional claims in published maps and institutional affiliations.

Copyright: (c) 2021 by the authors. Licensee MDPI, Basel, Switzerland. This article is an open access article distributed under the terms and conditions of the Creative Commons Attribution (CC BY) license (https:// creativecommons.org/licenses/by/ $4.0 /)$.

\begin{abstract}
Building Information Modeling (BIM) is recognized as one of the most significant technological breakthroughs in the Architecture, Engineering, and Construction (AEC) industry. The pace of implementation of BIM in AEC has increased during the past decade with an enhanced focus on sustainable construction. However, BIM implementation lags its potential because of several factors such as readiness issues, lack of previous experience in BIM, and lack of market demand for BIM. To evaluate and solve these issues, understanding the current BIM implementation in construction organizations is required. Motivated by this need, the main objective of this study is to propose a tool for the measurement of BIM implementation levels within an organization. Various sets of indexes are developed based on their pertinent Critical Success Factors (CSFs). A detailed literature review followed by a questionnaire survey involving 99 respondents is conducted, and results are analyzed to formulate a BIMp-Chart to calculate and visualize the BIM implementation level of an organization. Subsequently, the applicability of the BIMp-Chart is assessed by comparing and analyzing datasets of four organizations from different regions, including Qatar, Portugal, and Egypt, and a multinational organization to develop a global measurement tool. Through measuring and comparing BIM implementation levels, the BIMp-Chart can help the practitioners identify the implementation areas in an organization for proper BIM implementation. This study helps understand the fundamental elements of BIM implementation and provides a decision support system for construction organizations to devise proper strategies for the effectual management of the BIM implementation process.
\end{abstract}

Keywords: building information modeling (BIM); BIM implementation; critical success factors (CSFs); indexes; construction organization

\section{Introduction}

Due to its complicated and innovative projects, the construction industry is globally regarded as fragmented, uncertain, and complicated [1,2]. To overcome the problems and associated risks, numerous initiatives were launched to realize continuous improvement [3]. These efforts range from the adoption of new contractual/procurement arrangements such as partnering, concurrent engineering, and integrated project delivery to technological innovations in design and construction processes such as building information modeling (BIM) [4-7]. BIM is a digital representation of a facility's physical/functional characteristics that serves as a shared knowledge resource used for reliable decision-making during the 
life cycle [5]. BIM is adopted extensively in construction as it incorporates the technical aspects, knowledge disciplines, and implementation systems of a facility in a shared representation and virtual models as defined by ISO. It allows all team members to communicate, collaborate, visualize, and manage construction work better to ensure successful project delivery [8]. BIM allows superimposition of multi-disciplinary information in a virtual model, thus creating an opportunity to address sustainability measures and execute performance analyses from the planning to the operation stages [9]. These benefits of BIM, recognized by owners, persuade construction firms, construction managers, and other design professionals to implement it in their projects for sustainable construction [10].

BIM implementation rates have sharply increased around the developed economies [11]. A survey conducted between 2007-2012 in North America shows that BIM usage has increased from $28 \%$ in 2007 to $71 \%$ in 2012 [12]. In the UK, the BIM implementation rate was $13 \%$ in 2011 which grew to be $69 \%$ in 2019 [13]. Similarly, BIM implementation in Germany has reached up to $90 \%$ [14]. Furthermore, plenty of research has been conducted to explore the benefits of BIM implementation. By analyzing data from multiple construction companies, Yan and Demian [15] concluded that BIM implementation on construction projects leads to massive cost reduction and significant time-saving in the design and construction and during the operation phase. To investigate the benefits of practical BIM implementation, Azhar et al. [5] reviewed the case studies of two real projects. They indicated that BIM implementation provides significant time and cost savings on a construction project through early detection of clashes and enhanced design coordination. Similarly, Arayici et al. [16] analyzed the data of a construction firm to investigate the effects of BIM implementation in its projects and indicated that enhanced collaboration between team members and clash detection are major advantages through BIM, which contribute to time and cost savings and achieving a better quality of the project. Another study concluded that BIM implementation improves sustainability in the Indonesian construction industry [17]. This implies that the implementation of BIM is beneficial for the projects to enhance construction processes and sustainability.

Although BIM implementation is rising, its usage within construction organizations is highly dependent on many critical success factors (CSFs), such as government-led initiatives, support from leadership, unavailability of technological and financial resources, and availability of BIM expertise $[3,13,18,19]$. These CSFs can enhance or hinder the successful implementation of BIM in construction [18]. However, these present implementation challenges in BIM implementation in construction organizations lead to certain organizations backing off or being reluctant to adopt and implement BIM. The trend is more evident in developing countries or organizations with limited budgets and resources in developed countries such as small and medium-sized enterprises [13]. To evaluate and solve BIM implementation challenges, understanding its current implementation levels in construction organizations is essential [14]. Since BIM implementation is highly dependent on CSFs, their consideration is essential for the proper measurement of BIM within construction organizations.

Numerous researchers have attempted to measure the level of an organization's engagement with BIM. For this purpose, various BIM models have been developed. These models provide a detailed analysis of the BIM maturity level within the organization [20]. Moreover, some indexes were also developed to measure the BIM implementation level. These include depth of BIM implementation, expert users' percentage, usage experience, and adoption rates [21]. McGraw-Hill Construction [12] proposed the BIM engagement index to represent its implementation levels based on these indexes. Furthermore, a study developed BIM charts to visualize and measure its adoption and implementation levels [20].

The worldwide status of BIM adoption and implementation was also reported using the technology diffusion model [22], hype cycle model [23,24], BIM services [25], and the indexes mentioned above [26]. Most of these studies and surveys have employed similar indexes such as proficiency, years of using BIM, and its adoption rate $[1,16,18]$. Regardless of the similarities between the indexes used in previously conducted surveys, 
the focus of each survey was primarily on a single country or region at a particular time, concluded specifically for their particular context. These studies and surveys about specific regions might not provide much assistance to construction organizations located out of the studied zones. Further, due to the contextualized nature of the construction industries, some indexes might be inapplicable on a wider or global scale. This limitation necessitates a study to develop a measurement tool that uses a logical reason for selecting the indexes for measuring the BIM implementation level in a construction organization by taking a global perspective instead of restricting it to a locality or region. Such a study will allow the construction practitioners and researchers to compare and assess the BIM implementation level of multiple organizations according to a global scale rather than contextualizing it to a locality and struggling with another locality or region.

To overcome this limitation, this study adopts four main objectives: (1) to identify and validate CSFs for BIM implementation in construction organizations by capturing global BIM experts perspective, (2) to establish a set of indexes based on CSFs for the measurement of BIM implementation levels in different construction organizations, (3) to develop a BIM implementation chart based on the established indexes, and (4) to assess the applicability of the proposed implementation chart by comparing and analyzing datasets from different global organizations. The research outcomes are expected to deliver an improved global decision support system for BIM implementation that can help construction organizations define directions for future development regardless of their location or region.

\section{Literature Review}

Several studies have been conducted to measure the level of an organization's involvement with BIM [18,20,27,28]. Different models such as bimSCORE [24], BIM I-CMM [25], and BIM QuickScan [26] have been developed to facilitate the measurement of such involvement [25]. A summary of these models is provided in Table 1. These BIM models provide a detailed analysis of its maturity level, corresponding to the dexterity of its organizational use [20].

Table 1. Previously developed models for measuring BIM involvement in organizations.

\begin{tabular}{|c|c|c|c|c|}
\hline Sr. & Model & Methodology/Overview/Purpose & Outcome & Limitations \\
\hline 1 & bimSCORE & $\begin{array}{l}\text { bimSCORE acts like a "GPS Navigator" for } \\
\text { any enterprise or project team charting } \\
\text { a course for BIM. This online questionnaire } \\
\text { assists project teams and enterprises in } \\
\text { optimizing the value of BIM in four areas: } \\
\text { Planning, Adoption, Technology, } \\
\text { and Performance. }\end{array}$ & $\begin{array}{l}\text { Provides an analysis of } \\
\text { the BIM maturity level } \\
\text { within the } \\
\text { construction organization. }\end{array}$ & $\begin{array}{c}\text { Very complex and } \\
\text { require over } \\
200 \text { variables to function. }\end{array}$ \\
\hline 2 & BIM I-CMM & $\begin{array}{c}\text { BIM I-CMM is an interactive version of the } \\
\text { static excel maturity matrix originally } \\
\text { created by NIBS to evaluate information } \\
\text { management maturity on a scale in } \\
11 \text { different categories. } \\
\text { The tool's primary purpose was to show } \\
\text { how well BIM demonstrated the disparate } \\
\text { stakeholders of a facility collaborated } \\
\text { through their information } \\
\text { management practices. }\end{array}$ & $\begin{array}{c}\text { Provides an analysis of } \\
\text { the BIM maturity level } \\
\text { within the } \\
\text { construction organization. }\end{array}$ & Same as above \\
\hline 3 & BIM QuickScan & $\begin{array}{l}\text { BIM Quickscan consists of an online } \\
\text { questionnaire with almost } 50 \text { questions in } \\
4 \text { chapters (also called "categories"): } \\
\text { Organization and Management; Mentality } \\
\text { and Culture; Information structure and } \\
\text { Information flow; Tools and Applications. }\end{array}$ & $\begin{array}{l}\text { It provides insight into } \\
\text { the current BIM } \\
\text { performance and } \\
\text { maturity of a } \\
\text { construction } \\
\text { organization. }\end{array}$ & Same as above \\
\hline
\end{tabular}


Table 1. Cont.

\begin{tabular}{|c|c|c|c|c|}
\hline Sr. & Model & Methodology/Overview/Purpose & Outcome & Limitations \\
\hline 4 & $\begin{array}{l}\text { BIM Engagement } \\
\text { Index }\end{array}$ & $\begin{array}{l}\text { BIM Engagement index quantifies the } \\
\text { user's engagement with BIM with } \\
\text { a numerical score. The score is derived } \\
\text { using three types of indexes: Experience, } \\
\text { Expertise, and Implementation. }\end{array}$ & $\begin{array}{c}\text { Measure the level of } \\
\text { construction } \\
\text { organization's } \\
\text { engagement with BIM. }\end{array}$ & $\begin{array}{c}\text { Use a similar set of } \\
\text { commonly available } \\
\text { variables that do not } \\
\text { cover all the critical areas } \\
\text { of an organization. }\end{array}$ \\
\hline 5 & Slim BIM Charts & $\begin{array}{l}\text { Slim BIM charts, namely diamond, triangle, } \\
\text { and ball charts, measure BIM adoption and } \\
\text { implementation levels using four types of } \\
\text { indexes: BIM adoption rate, years of using } \\
\text { BIM, level of proficiency, and depth } \\
\text { of implementation. }\end{array}$ & $\begin{array}{l}\text { Measure the level of } \\
\text { BIM adoption and } \\
\text { implementation within } \\
\text { the construction } \\
\text { organization. }\end{array}$ & Same as above \\
\hline
\end{tabular}

Moreover, various indexes have also been developed to measure the levels of BIM implementation that correspond to BIM usage levels in an organization [20]. By exploring the published literature, it was noted that the level of involvement, level of proficiency, and years of using BIM is regularly used indexes for measuring BIM implementation $[20,23,24]$. These indexes were first developed by Jung and Lee [24] for the measurement of BIM adoption and implementation in construction organizations. These have been used in subsequent surveys along with the BIM adoption rate. The technology diffusion model and the hype cycle model were utilized to measure BIM implementation [26].

McGraw-Hill Construction Research \& Analytics has described several survey results on adopting and implementing BIM in the SmartMarket Report since 2007 [24]. They were the first to introduce the BIM adoption rate as one of the BIM adoption and implementation measures. In 2009, the SmartMarket report classified the same into two values, i.e., BIM adoption rate for measuring the adoption and the level of involvement for the measurement of BIM implementation $[20,24]$. The BIM adoption rate was aimed at the percentage of respondents using BIM, while the depth of involvement referred to the percentage of BIM projects. The level of involvement was categorized into four levels: light use $(<16 \%$ of projects), moderate use (16-29\%), heavy use (30-59\%), and very heavy use (>60\%) [20]. Since 2008, this classification has been utilized in several surveys reporting BIM implementation levels [20,26].

Another index commonly used to measure BIM implementation is years of using BIM [20,24,26]. This index shows the percentage of BIM users within the target group that has used BIM for more than five years [8]. McGraw-Hill Construction [12] proposed the BIM engagement index to represent the BIM implementation levels based on these indexes. Other models are also available for measuring BIM implementation. These include the hype cycle model [23] and the technology diffusion model contextualized to BIM [29]. The hype cycle model is used to measure the potential and maturity of the technology, BIM in this case. It comprises five phases: phases 1 and 2 are generally regarded as "early phase", while phases 3,4, and 5 refer to "moderate", "mature", and "very mature" phases, respectively [26]. On the other hand, the technology diffusion model determines the major users of new technology (BIM). It also consists of five groups: "innovators" or the first $2.5 \%$ users, "early adopters" or the additional 13.5\%, "early majority" or the additional $34 \%$ (first 50\%), "late majority" or the next 34\% (initial 84\%) and "laggards" or the last $16 \%$ of all the users.

Jung and Lee [24] proposed three types of BIM charts, namely diamond, triangle, and ball charts, to measure BIM adoption and implementation levels using four types of indexes. These include BIM adoption rate, years of using BIM, level of proficiency, and depth of implementation. These charts were then exercised to report BIM adoption and implementation in North America, South Korea, and Western Europe. According to the results, BIM was most widely adopted and implemented in North America compared to the other two regions. 
The analysis of the relevant studies revealed that these developed models still lack the required efficiency. Models such as bimSCORE, BIM I-CMM, and BIM QuickScan are very complex and require over 200 variables to function [24]. Furthermore, BIM Engagement Index [12] and Slim BIM charts [24] were developed to measure BIM adoption and implementation levels, ease the process using fewer variables, and relatively simple calculation methods. However, these models use a similar set of commonly available variables that do not cover all the critical areas of an organization. None of these studies shortlisted the critical variables that need to be addressed and then develop indexes around them covering all the key aspects of BIM implementation in an organization.

Hence, there is a need for a tool that can measure BIM implementation levels based on a critical set of variables by using indexes covering all the key aspects of BIM implementation rather than only using commonly available indexes. The research team first proposed the concept of a BIM chart related to BIM implementation at Yonsei University in $2012[20,24]$. The main objective of these charts was to visualize and quantify levels of BIM adoption and implementation rapidly. Similarly, the BIMp-Chart in this study, implying BIM-Implementation Chart, is proposed to help measure the overall BIM implementation level in an organization, aiming to make the procedure easier and achieve more accurate results. This chart will also help organizations to compare their BIM implementation level with other organizations. This comparison will boost the organizations to improve their implementation level and achieve maximum benefits from BIM through proper implementation.

\section{Materials and Methods}

A comprehensive research methodology comprising three qualitative stages was adopted to achieve the defined objectives, as shown in Figure 1.

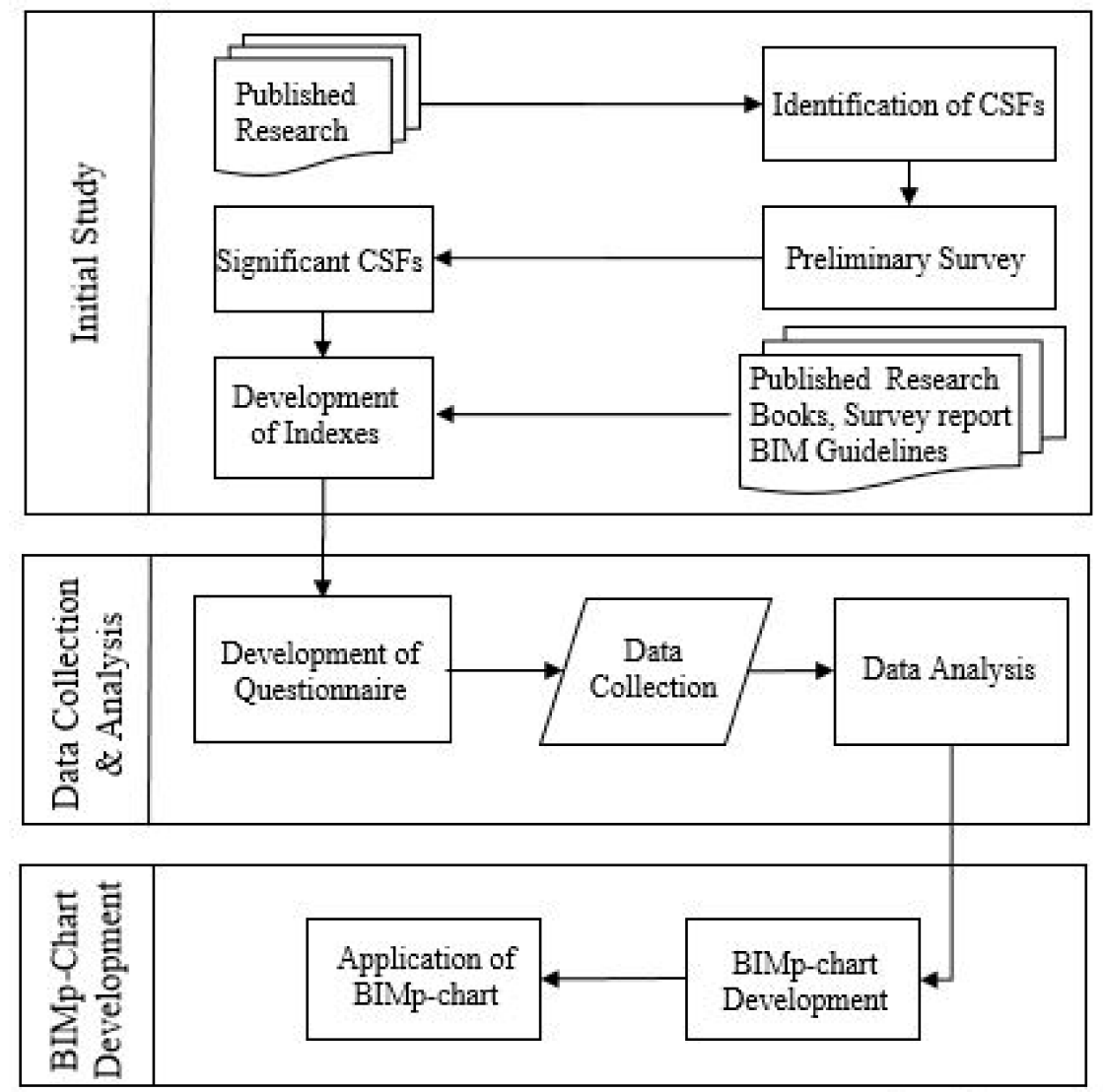

Figure 1. Flowchart of research methodology. 
In the first phase, CSFs for BIM implementation were identified by a thorough literature review of 72 systematically retrieved papers. A preliminary survey was then conducted to highlight the significant CSFs by incorporating the opinions of BIM experts. The next step was developing indexes based on shortlisted CSFs identified for measuring BIM implementation level in organizations through a detailed literature review in the subsequent section.

In the second phase, indexes developed from the past research were incorporated into the second online questionnaire survey. This second survey-the main for this study-aimed to determine the extent of agreement for the developed indexes from global BIM experts. In the third and final phase, the collected data were analyzed to develop a BIM implementation chart, followed by its application and pertinent discussions.

\subsection{Identification of CSFs for BIM Implementation}

Many studies have highlighted critical factors that affect the successful implementation of BIM in construction. However, previous studies were mainly subjected to particular regions or economies and did not consider the global perspective. Moreover, it is also observed that BIM has better adoption and implementation in industrially developed economies than in developing countries. Furthermore, the existing factors are mostly identified and tailored for developed countries and cannot be implemented in developing economies due to contextual and logistic reasons. This warrants a new and customized identification of CSFs for BIM implementation by incorporating the global perspective. However, since the technical vigor and robustness cannot be compromised, experts from both the developing and developed parts of the globe must come together to inform and advise in identifying unified CSFs for BIM implementation.

\subsubsection{Review and Synthesis of Existing Research}

Based on the previous research regarding BIM implementation, critical success factors have been recognized from published literature. For searching the literature, Web of Science and Scopus repositories were used as shown in Table 2. Keywords used in the searching process include "BIM", "BIM implementation", "BIM CSFs", "BIM barriers", and "BIM challenges". These keywords were used in conjunction with the word "construction" and joined by Boolean operators AND or to formulate the search strings. These keywords were searched for in the title, abstract, and keywords of the articles to be retrieved by the search engines of Scopus and Web of Science. Further, the search areas were restricted to social science and engineering only and further refined to civil and construction engineering only to retrieve construction-focused articles. The document type was restricted to journal articles only as these are considered high-quality literature as claimed by Qayyum et al. [6] and Ullah et al. [7]. These resulted in 262 articles containing 142 from Scopus and 120 from the Web of Science. A total of 108 duplicates were found where both repositories indexed these articles and hence counted once. Further, 37 articles were found to have a non-construction focus when the articles were read in detail thus these were also removed.

As a result, a total of 115 articles published between the years 2010-2021 were extracted. This specific period is selected to focus on recent trends in this research domain. For the evaluation, articles were reviewed to ensure that they contain information about critical success factors of BIM implementation. This exercise resulted in a focused selection of 74 articles for further analysis. Sixty-three factors were retrieved from the literature and were reduced to 33 factors by merging and renaming some factors that appear to have a similar meaning to avoid repetition.

These systematically identified CSFs from the literature, along with their description, are listed in Table 3. Similar review and literature retrieval method has been adopted in recent review studies [6,28,30-32]. 
Table 2. Literature retrieval.

\begin{tabular}{|c|c|c|c|}
\hline Sr. & Search Engine & Search Strings & Count \\
\hline \multirow{4}{*}{1} & \multirow{4}{*}{ Scopus } & $\begin{array}{c}\text { (TITLE-ABS-KEY (bim) OR TITLE-ABS-KEY (bim AND implementation) OR } \\
\text { TITLE-ABS-KEY (bim AND csfs) OR TITLE-ABS-KEY (bim AND barriers) } \\
\text { OR TITLE-ABS-KEY (bim AND challenges) AND } \\
\text { TITLE-ABS-KEY (construction)) }\end{array}$ & 7262 \\
\hline & & $\begin{array}{l}\text { AND (LIMIT-TO (SUBJAREA, “ENGI”) OR LIMIT-TO (SUBJAREA, “SOCI”) } \\
\text { OR LIMIT-TO (SUBJAREA, “DECI")) }\end{array}$ & 4830 \\
\hline & & $\begin{array}{l}\text { AND (LIMIT-TO (DOCTYPE, “ar”)) AND (LIMIT-TO (LANGUAGE, } \\
\text { “English”)) AND (LIMIT-TO (SRCTYPE, “j”)) }\end{array}$ & 1166 \\
\hline & & AND PUBYEAR < 2011 & 142 \\
\hline \multirow{11}{*}{2} & \multirow{6}{*}{ Web of Science } & $\begin{array}{c}\text { You searched for: TOPIC: (BIM) OR TOPIC: (BIM implementation) OR } \\
\text { TOPIC: (BIM CSFs) OR TOPIC: (BIM barriers) OR TOPIC: (BIM challenges) } \\
\text { AND TOPIC: (Construction) }\end{array}$ & 11,315 \\
\hline & & $\begin{array}{l}\text { Timespan: 2010-2021. Indexes: SCI-EXPANDED, SSCI, A\&HCI, CPCI-S, } \\
\text { CPCI-SSH, BKCI-S, BKCI-SSH, ESCI, CCR-EXPANDED, IC. }\end{array}$ & 3173 \\
\hline & & Categories: (Engineering Civil OR Construction Building Technology) & 1907 \\
\hline & & Types: (Article) & 1786 \\
\hline & & AND Languages: (English) & 1140 \\
\hline & & $\begin{array}{l}\text { AND Research Areas: (Construction Building Technology) } \\
\text { AND Web of Science Index: (WOS.SSCI) }\end{array}$ & 120 \\
\hline & & Total & 262 \\
\hline & & Duplicates & 108 \\
\hline & & Non-Construction Focus & 37 \\
\hline & & Final Articles & 115 \\
\hline & & FS for BIM Implementation Focused Articles & 74 \\
\hline
\end{tabular}

Table 3. Identified CSFs.

\begin{tabular}{|c|c|c|c|c|}
\hline Sr. & Factor & $\begin{array}{l}\text { Normalized } \\
\text { Literature Score }\end{array}$ & Description & Selected Reference \\
\hline 1 & Training of employees & 0.0845 & $\begin{array}{l}\text { Teaching and learning activities are carried out to } \\
\text { facilitate the members of the organization on the use of } \\
\text { different tools and new processes of BIM. }\end{array}$ & {$[1,33,34]$} \\
\hline 2 & $\begin{array}{l}\text { Financial resources } \\
\text { for BIM }\end{array}$ & 0.0445 & $\begin{array}{l}\text { Availability of sufficient budget required for the } \\
\text { implementation of BIM within the organization. }\end{array}$ & {$[3,35,36]$} \\
\hline 3 & $\begin{array}{l}\text { Awareness level about } \\
\text { BIM benefits }\end{array}$ & 0.0815 & $\begin{array}{l}\text { Awareness and understanding of the advantages of } \\
\text { BIM at each stage of its process. }\end{array}$ & {$[37,38]$} \\
\hline 4 & BIM expertise & 0.0845 & $\begin{array}{l}\text { The availability of skilled and technological experts } \\
\text { within the organization implementing BIM. }\end{array}$ & {$[8,34,35]$} \\
\hline 5 & Willingness to change & 0.0845 & $\begin{array}{l}\text { The conservativeness of organization to shift from } \\
\text { traditional methods and averse comfortable routines. }\end{array}$ & {$[37,39,40]$} \\
\hline 6 & BIM vision & 0.0519 & $\begin{array}{l}\text { The vision statement of the organization sets the tone } \\
\text { for the future of BIM and provides the staff with } \\
\text { an outlook of its importance. }\end{array}$ & {$[39,41,42]$} \\
\hline 7 & $\begin{array}{l}\text { Top management } \\
\text { involvement }\end{array}$ & 0.0697 & $\begin{array}{l}\text { Involvement and commitment of the organization's top } \\
\text { management to expedite the use of BIM. }\end{array}$ & {$[3,11,42]$} \\
\hline 8 & Availability of IT resources & 0.0282 & $\begin{array}{l}\text { Availability of information and technology necessary } \\
\text { for BIM implementation within the organization. }\end{array}$ & {$[43,44]$} \\
\hline 9 & $\begin{array}{l}\text { Employer Information } \\
\text { Requirement for BIM }\end{array}$ & 0.0282 & $\begin{array}{c}\text { Client's interest and enforcement to use BIM for } \\
\text { their projects. }\end{array}$ & {$[1,45]$} \\
\hline
\end{tabular}


Table 3. Cont.

\begin{tabular}{|c|c|c|c|c|}
\hline Sr. & Factor & $\begin{array}{l}\text { Normalized } \\
\text { Literature Score }\end{array}$ & Description & Selected Reference \\
\hline 10 & $\begin{array}{l}\text { Government supporting } \\
\text { initiatives }\end{array}$ & 0.0726 & $\begin{array}{l}\text { The steps taken by the government to support the } \\
\text { implementation of BIM. }\end{array}$ & {$[11,46,47]$} \\
\hline 11 & Legal parameters & 0.0237 & $\begin{array}{l}\text { Existence of guidelines on legal issues such as data } \\
\text { sharing, ownership of data, access to BIM platforms, } \\
\text { transparency, and licensing. }\end{array}$ & {$[11,48,49]$} \\
\hline 12 & $\begin{array}{l}\text { Coordination among } \\
\text { project parties }\end{array}$ & 0.0193 & $\begin{array}{l}\text { Existence of collaborative environment } \\
\text { between project parties. }\end{array}$ & [50-52] \\
\hline 13 & $\begin{array}{l}\text { Technical supports for } \\
\text { interoperability issues }\end{array}$ & 0.0163 & $\begin{array}{l}\text { Existence of technical support for interoperability such } \\
\text { as IFC, IDM, etc. }\end{array}$ & {$[49,53,54]$} \\
\hline 14 & Organizational structure & 0.0771 & $\begin{array}{l}\text { Assignment of new roles and responsibilities to } \\
\text { examine and improve the application of BIM. }\end{array}$ & {$[40,55]$} \\
\hline 15 & $\begin{array}{l}\text { Incentives programs } \\
\text { from client }\end{array}$ & 0.0133 & $\begin{array}{l}\text { Encouragement by the client by giving incentives such } \\
\text { as tax reduction etc. }\end{array}$ & {$[34,50,55]$} \\
\hline 16 & Project characteristics & 0.0133 & $\begin{array}{l}\text { The aspects of the project such as size, } \\
\text { budget, location, etc. }\end{array}$ & {$[33,40]$} \\
\hline 17 & Information management & 0.0089 & $\begin{array}{l}\text { Existence of practical and well-developed strategies for } \\
\text { the purposeful exchange of information. }\end{array}$ & {$[43,49]$} \\
\hline 18 & $\begin{array}{l}\text { Experience level within } \\
\text { the organization }\end{array}$ & 0.0741 & $\begin{array}{l}\text { Existence of previous experience pertinent to BIM } \\
\text { implementation within the organization. }\end{array}$ & {$[40,52,56]$} \\
\hline 19 & $\begin{array}{l}\text { Knowledge sharing within } \\
\text { the industry }\end{array}$ & 0.0089 & $\begin{array}{c}\text { Existence of platforms such as conferences, seminars, } \\
\text { workshops, etc. to facilitate learning } \\
\text { among organizations. }\end{array}$ & {$[39,50,55]$} \\
\hline 20 & $\begin{array}{l}\text { Available capacity } \\
\text { building support from } \\
\text { Academia/industry }\end{array}$ & 0.0074 & $\begin{array}{l}\text { Availability of consultancy services from other } \\
\text { organizations, universities, etc. }\end{array}$ & {$[8,10,43]$} \\
\hline 21 & $\begin{array}{l}\text { SOP for BIM } \\
\text { implementation }\end{array}$ & 0.0074 & $\begin{array}{l}\text { Selection of proper BIM procedures sufficiently } \\
\text { fulfilling the needs of the organization. }\end{array}$ & {$[3,5,54]$} \\
\hline 22 & Time required for training & 0.0059 & $\begin{array}{l}\text { Learning time required for the training to implement } \\
\text { BIM successfully. }\end{array}$ & {$[19,35,57]$} \\
\hline 23 & Risk management & 0.0044 & Management of risks arising when implementing BIM. & {$[42,48,58]$} \\
\hline 24 & Trust & 0.0059 & $\begin{array}{l}\text { Collaborative spirit and mutual trust between the } \\
\text { members of the organization. }\end{array}$ & {$[43,55]$} \\
\hline 25 & Suppliers using BIM tools & 0.0044 & $\begin{array}{l}\text { Lack of understanding among suppliers for } \\
\text { using BIM tools }\end{array}$ & {$[39,42,51]$} \\
\hline 26 & $\begin{array}{l}\text { Abundant BIM } \\
\text { content Libraries }\end{array}$ & 0.0044 & Availability of BIM Object and Parametric library. & {$[53,59]$} \\
\hline 27 & Security concerns & 0.0044 & $\begin{array}{l}\text { Issues related to the security of the model e.g., } \\
\text { unauthorized access, e-documents are still vulnerable to } \\
\text { viruses, hacking }\end{array}$ & {$[60,61]$} \\
\hline 28 & $\begin{array}{l}\text { External stakeholders' } \\
\text { involvement }\end{array}$ & 0.0044 & $\begin{array}{l}\text { External stakeholder's engagement in BIM dynamic } \\
\text { and facilitating the transition. }\end{array}$ & {$[49,62]$} \\
\hline 29 & $\begin{array}{l}\text { Model sharing } \\
\text { among disciplines }\end{array}$ & 0.0044 & Different disciplines sharing models in a "Big Room". & {$[49,63]$} \\
\hline 30 & Level of information & 0.0030 & $\begin{array}{l}\text { Ability to maintain quality information in } \\
\text { the BIM models. }\end{array}$ & {$[35,64]$} \\
\hline 31 & Size of organization & 0.0548 & $\begin{array}{l}\text { Size of an organization depending on the } \\
\text { number of employees. }\end{array}$ & {$[40,52,65]$} \\
\hline 32 & Continuous Learning & 0.0025 & $\begin{array}{l}\text { The concept of learning new skills and knowledge on } \\
\text { an ongoing basis exists in the organization. }\end{array}$ & {$[66,67]$} \\
\hline 33 & $\begin{array}{l}\text { Task team member's } \\
\text { interest to implement BIM }\end{array}$ & 0.0015 & $\begin{array}{l}\text { Field engineers perceiving the value of implementing } \\
\text { their part of BIM. }\end{array}$ & [68-70] \\
\hline
\end{tabular}

To determine the Literature Score (LS), a two-step content analysis was performed using quantitative and qualitative analysis of identified factors. For quantitative assessment, 
the relative frequency of appearance in the selected articles was used. In comparison, the qualitative assessment was carried out by observing the impact of factors in the views of respective researchers for placing them into three impact categories of High, Medium, and Low $[50,56,71]$. The LS of each factor was then converted into normalized score using Equation (1) [72].

$$
\text { Normalized Score }=\frac{\text { score of individual factor }}{\text { sum of score of all factors }}
$$

For example, consider the normalized score for the factor "Training of employees" from Table 1. The individual score for this factor is 0.4750 and the sum of scores for all factors is 5.6222 , thus, the normalized score for this factor will be as follows.

$$
0.4750 / 5.6222=0.0845
$$

Using the same approach, normalized scores are calculated for all factors. This is conducted to check the extent of influence of CSFs, concerning the total number of responses. However, the subjectivity in understanding results and conclusions of published articles cannot be excluded, and consequently, the responsibility is completely assumed by the authors of this paper.

\subsubsection{Preliminary Survey}

After shortlisting $33 \mathrm{CSFs}$, an online questionnaire survey was conducted to rate the identified CSFs based on their importance towards BIM Implementation. For this purpose, worldwide BIM experts were contacted. Experts were located firstly through online searching of the construction companies implementing BIM and looking at their BIM experts from the company profile. Such BIM experts were contacted through official email. Secondly, BIM experts were also identified through the LinkedIn platform and contacted subsequently using both convenient sampling and snowballing approaches of sampling. The questionnaire was administered to the BIM experts worldwide who were requested to provide input on the practices and views of BIM in the construction industry. Practitioners having more than three years of experience in BIM were targeted for more reliable responses. The respondents were asked to assign scores to the CSFs based on their knowledge and experience on a 5-point Likert scale. A total of 76 completed questionnaires were received for analysis out of 231 sent out, resulting in a $32.9 \%$ response rate. The response rate is satisfactory as it is not lower than 30\% [34]. These experts hail from different countries, including China (13), USA (12), UK (9), Pakistan (8), Qatar (7), Canada (7), Australia (6), Portugal (4), Egypt (4), Jordan (3), and others (3).

Afterward, the reliability of the collected data was checked through Cronbach's alpha test. The results show the inter-correlation score of 0.92 , above the threshold value of 0.7 [73]. To recognize the current industry trend on the identified CSFs, the relative importance index (RII) was calculated using the formula given in Equation (2) for each factor, where I is impact assigned to each factor, $n$ is the sample size, and $H$ is the highest impact. RII was then normalized in reference to Equation (1).

$$
R I I=\sum I n \times H
$$

By merging normalized RII with normalized LS, a Total Score (TS) through Equation (3) was calculated for each factor [74]. Giving more value to industry experts, a weighting split of 60/40 ratio was used to calculate TS using Equation (3), wherein 60 percent weightage was assigned to the field survey scores and 40 percent to the literature scores to develop the final rankings of CSFs.

$$
T S=(0.6 \times \text { normalised } R I I)+(0.4 \times \text { normalised } L S)
$$


The cumulative scores (CS) were then calculated for the factors using Equation (4). Based on more than 50\% cumulative scores, the top 10 factors listed in Table 4 were attained by following the method adopted by Amuda-Yusuf [75].

$$
C S=T S \text { of individual factor }+ \text { sum of its predecessors }
$$

Table 4. Ranking of CSFs.

\begin{tabular}{cccc}
\hline Sr. & Factors & $\mathbf{6 0 / 4 0}$ & Cumulative \\
\hline 1 & Training of employees & 0.056183 & 0.056182526 \\
2 & BIM expertise & 0.056183 & 0.112365052 \\
3 & Willingness to change & 0.056183 & 0.168547578 \\
4 & Awareness level about BIM benefits & 0.054997 & 0.223544334 \\
5 & Top management involvement & 0.050254 & 0.273798006 \\
6 & Organizational structure & 0.04874 & 0.322538493 \\
7 & Experience level within the organization & 0.047555 & 0.37009321 \\
8 & Government supporting initiatives & 0.046962 & 0.417055041 \\
9 & BIM vision & 0.043139 & 0.460194089 \\
10 & Size of organization & 0.039847 & 0.500041295 \\
\hline
\end{tabular}

\subsection{Development of Indexes}

BIM implementation within an organization is highly dependent on pertinent CSFs [48,64,75]. To achieve the objective of gauging the BIM implementation level in construction organizations, indexes were developed to measure shortlisted CSFs. For this purpose, on the one hand, research articles, books, and BIM guides were searched using keywords such as BIM, BIM implementation, BIM measurement, BIM training, BIM roles, etc. While on the other hand, 15 survey reports, 7 BIM guides, and 5 books were also identified for the study from the same sources as previously mentioned in the factor identification section. Initially, a total of 179 articles were retrieved. Abstracts and conclusions of the retrieved articles were studied to check if they contain any information regarding shortlisted CSFs. This exercise resulted in the selection of 132 articles. These articles were analyzed in detail to check if they contain any information relevant to the measurement of those CSFs. As a result, irrelevant papers were eliminated, resulting in the shortlisting of 82 papers for further study. Data from survey reports, BIM guides, and books were studied and analyzed thoroughly to develop measurement levels regarding BIM implementation in construction organizations. The next step was to conduct a worldwide survey targeting BIM experts. There were two main goals of the survey: first, to validate the developed indexes and second, to acquire suggestions for improving indexes.

Initially, the study aimed at categorizing all the indexes into equal numbers of levels to avoid complications in measurement. Most of the indexes in previous studies were divided into four levels for measurement. For example, the construction companies are defined under four categories, level of proficiency, level of involvement, and under BIM maturity, all comprise four levels [35]. Therefore, this study also divided each index into four levels for the measurement of each critical factor. These indexes and descriptions of their respective defined levels are subsequently discussed and presented in Table 5.

\subsubsection{Training of Employees}

Due to the unavailability of an index that can measure the training of employees in the BIM context, literature was explored wherein discussions of researchers were observed regarding the type of training necessary for successful BIM implementation within construction organizations. For example, Smith [11] and Azhar et al. [5] mentioned that a critical part of education beyond the teaching of concepts and BIM applications within an organization is concerned with technical training for particular BIM tools. This necessitates both technical education of BIM concepts and features for transitioning from CAD to 3D parametric modeling. Further software training is required to fully leverage multiple integrations and interoperability benefits that BIM offers [34]. Vass and Gustavsson [76] 
concluded that proper model creation training, sharing, and integration are critical to enhancing BIM implementation in a project. This signifies the need for training at all employment levels: entry, foundational, intermediate, and advanced. Considering the discussion above and relevant literature about the index, the proposed training index is suggested to have entry, foundational, intermediate, and advanced levels.

\subsubsection{BIM Expertise}

A widely used index and proficiency level can be used to measure BIM expertise levels within an organization. Different surveys have used this index under different classifications. However, all of them evaluate the level of proficiency by relying on the selfevaluation of BIM users about the confidence level of their BIM expertise. This highlights that categorization by users in the given levels is subjective to their understanding. To overcome this problem, literature related to expertise in BIM was investigated. The research by Wang et al. [63], which defines staff ability levels, described the basic levels into which BIM expertise can be classified. To suggest levels according to the requirements of this study into greater detail, four levels were devised: beginner, moderate, advanced, and expert. Two terminologies, i.e., primary and secondary BIM services, were used in these proposed levels. To avoid any confusion and provide the organizations with a clear description of the defined levels, the depiction of primary and secondary BIM services proposed by Khosrowshahi and Arayici [77] is used. Accordingly, primary BIM services include existing conditions modeling, cost estimation, phase planning, programming, site analysis, design review, design authoring, energy analysis, 3D coordination, site utilization planning, 3D control and planning, record model, maintenance scheduling, and building system analysis. On the other hand, secondary BIM services are related to structural analysis, lightning analysis, mechanical analysis, other emerging analysis, sustainability analysis, code validation, construction system design, digital fabrication, asset management, space management, and disaster planning and management.

\subsubsection{Willingness to Change}

During the literature review, it was observed that the technology diffusion model could be used for the measurement of willingness to change. For this study, the first two groups (innovator and early adopters) were merged to divide the whole index into four uniform levels, i.e., laggards (last 16\%, i.e., 85-100), late majority (51-84\%), early majority (16-49\%), and early adopters (first 15\%). These levels were based on percentages representing the early involvement of an organization with BIM compared to other organizations in a particular industry.

\subsubsection{Awareness Level about BIM Benefits}

Many organizations are familiar with BIM and evaluate it actively but primarily focus on model geometry [35]. Limited organizations recognize that the value of the digital model goes well beyond its geometric representation and has more to do with its information [43]. Moreover, even fewer of them understand the value of good geometric and structured data-enriched models [78]. ISO [79] provided the basis for defining levels within this index that pertains to the perception of an organization about BIM. This resulted in the definition of four levels considered in the current study: consideration, involvement, understanding, and valuing, elaborated in Table 5.

\subsubsection{Top Management Involvement}

Several surveys use the level of involvement developed by McGraw-Hill Construction [21] for measuring the percentage of projects on which BIM is utilized. Literature suggests that top management involvement deals with the approach and commitment of management to expedite BIM within an organization [80]. Therefore, this particular index was used to measure the involvement of management in BIM. Four levels, namely light use, medium use, heavy use, and very heavy use, were utilized for the subject index as proposed by 
McGraw-Hill Construction [21]. The defined levels pertain to the application of BIM on a certain percentage of projects within an organization.

\subsubsection{Organization's Structure}

The successful implementation of BIM demands the development of new roles $[27,43,48]$. Literature and BIM guides such as Joseph [81], McArthur and Sun [82], NBS [83], McArthur and Sun [82], Kensek [84], and others were consulted to realize the important roles involved in an improved BIM implementation within an organization. Five roles were found to have a vital role in the context. Each role was precisely defined and assigned with its respective responsibility in the referred guidelines and discussed in the following section.

The model author(s) or the modeler(s), identified as a basic role, is a person/team responsible for the creation and maintenance of BIM models [40]. On a leading level, the BIM manager is accountable for tracking and controlling errors and making responsibilitiesrelated decisions. The BIM manager is responsible for implementing activities of security, software, parties' agreement on model access, archiving, information, etc. [44]. BIM implementation also entails a BIM coordinator that reallocates power and decision-making [76]. Moreover, for the organizations undertaking larger and complex projects on a fast-track basis, the main technical design disciplines (structural, architectural, MEP, etc.) have BIM task team managers to synchronize their work with the entire design/construction team $[58,79,83]$. The role of information manager is particularly described in the Construction Industry Council BIM protocol, which is responsible for establishing and managing the information procedures, protocols, and processes for the project, including other aspects such as file management, information exchange, and common data environment for the project [85]. Although this role commonly falls under the BIM manager category, some guides define it in exclusion [86]. Considering these roles, organizational hierarchy is developed for each level: basic, moderate, mature and seasoned, as presented in Table 5.

\subsubsection{Experience Level within the Organization}

Many studies conducted in the BIM domain evaluate respondents' experience level based on their years of working with BIM $[8,10]$. On this basis, an existing index proposed by McGraw-Hill Construction [12], i.e., the percentage of BIM users within the target group who have used BIM for more than five years, was used to measure the experience level within the organization. This percentage was divided into four levels for the current study: limited experience, moderate experience, fairly good experience, and good experience, as presented in Table 5.

\subsubsection{Government Supportive Initiatives}

Recently, governments of various countries have started to encourage, specify, or mandate BIM implementation in construction projects [49]. However, some laggard groups still exist because of no major involvement of their governments [85]. Several initiatives were taken by the governments of different countries, such as providing BIM training programs, certification, licenses, awareness and motivation programs, tax reduction, subsidizing training, software, and consultancy $[39,42,87]$. These initiatives to increase BIM implementation were studied from the published articles. Accordingly, four levels were developed to measure the supportive government initiatives, including zero role, basic role, guiding role, and leading role, with descriptions given in Table 5.

\subsubsection{BIM Vision}

To measure BIM vision, literature was explored, and data were gathered on how organizations define their vision. BIM vision statement is a long-term view of the organization that sets the tone for the future of the organization $[88,89]$. Keeping this in view, the visions of the various organizations using BIM were studied. It was noted that most organizations established their vision from the perspective of BIM levels they target. Based on BIM 
maturity levels, four levels were developed for BIM vision: beginner, moderate, advanced, and expert. These levels are defined in Table 5.

Table 5. Set of indexes.

\begin{tabular}{|c|c|c|c|}
\hline Sr. & Level Type & Level Description & Selected Reference \\
\hline \multicolumn{4}{|c|}{ Training of employees } \\
\hline 1 & Entry & $\begin{array}{l}\text { Introduction to BIM and Technical education on BIM } \\
\text { concepts and features. }\end{array}$ & {$[11,90]$} \\
\hline 2 & Foundational & $\begin{array}{l}\text { Hands-on Exercise on basic skills needed for parametric modeling and } \\
\text { producing drawings. }\end{array}$ & {$[34,35,90]$} \\
\hline 3 & Intermediate & $\begin{array}{l}\text { Training on how to work in a shared and published information } \\
\text { environment (common data environment). }\end{array}$ & {$[11,43,90]$} \\
\hline 4 & Advanced & $\begin{array}{l}\text { Training on the utilization of software tools to apply different } \\
\text { dimensions of BIM. }\end{array}$ & {$[35,37,43]$} \\
\hline \multicolumn{4}{|c|}{ BIM expertise } \\
\hline 1 & Beginner & $\begin{array}{l}\text { Majority of the BIM users in the organization know about primary BIM } \\
\text { services but cannot apply them without assistance. }\end{array}$ & {$[12,20,24,63]$} \\
\hline 2 & Moderate & $\begin{array}{l}\text { Majority of the BIM users in the organization can apply primary BIM } \\
\text { services with little supervision but need supervision to apply secondary } \\
\text { BIM services. }\end{array}$ & {$[12,20,24,63]$} \\
\hline 3 & Advanced & $\begin{array}{l}\text { Majority of the BIM users in the organization can apply primary and } \\
\text { secondary BIM services without supervision and can apply new } \\
\text { on their own. }\end{array}$ & {$[12,20,24,63]$} \\
\hline 4 & Expert & $\begin{array}{c}\text { Majority of the BIM users in the organization can apply primary and } \\
\text { secondary BIM services without supervision and can create new } \\
\text { applications areas with BIM. }\end{array}$ & {$[12,20,24,63]$} \\
\hline \multicolumn{4}{|c|}{ Willingness to change } \\
\hline 1 & Laggards & $\begin{array}{l}\text { Organization is among the last } 16 \% \text { of the organizations that adopted } \\
\text { BIM in a specific country. }\end{array}$ & {$[26,29,59]$} \\
\hline 2 & Late majority & $\begin{array}{l}\text { Organization is among } 51 \text { to } 84 \% \text { of the organizations that adopted BIM } \\
\text { in a specific country. }\end{array}$ & {$[26,29,59]$} \\
\hline 3 & Early majority & $\begin{array}{l}\text { Organization is among } 17 \text { to } 50 \% \text { of the organizations that adopted BIM } \\
\text { in a specific country. }\end{array}$ & {$[26,29,59]$} \\
\hline 4 & Early adopters & $\begin{array}{l}\text { Organization is among the first } 16 \% \text { of the organizations that adopted } \\
\text { BIM in a specific country. }\end{array}$ & {$[26,29,59]$} \\
\hline \multicolumn{4}{|c|}{ Awareness level about BIM benefits } \\
\hline 1 & Consideration & $\begin{array}{l}\text { Still becoming familiar with the topic, actively evaluating BIM, believing } \\
\text { it as useful, and exploring its potential. }\end{array}$ & {$[12,29,43]$} \\
\hline 2 & Involvement & $\begin{array}{l}\text { Focus lies primarily in model geometry. BIM use-cases for people in this } \\
\text { group revolve around model creation, visualization, clash detection, and } \\
\text { other model coordination. }\end{array}$ & {$[38,78,91]$} \\
\hline 3 & Understanding & $\begin{array}{l}\text { Recognized that the value of the digital model goes well beyond its } \\
\text { geometric representation and has more to do with its information. } \\
\text { Understand that well-structured, high quality, data-rich models are the } \\
\text { basis of all BIM processes. }\end{array}$ & {$[38,78,90,91]$} \\
\hline 4 & Valuing & $\begin{array}{c}\text { Understanding the value of good geometric and structured data enriched } \\
\text { models. However, above all, they recognize BIM with process } \\
\text { management, defining and executing workflows to manage } \\
\text { digitally-enabled tasks. }\end{array}$ & {$[38,78,90,91]$} \\
\hline
\end{tabular}


Table 5. Cont.

\begin{tabular}{|c|c|c|c|}
\hline Sr. & Level Type & Level Description & Selected Reference \\
\hline \multicolumn{4}{|c|}{ Top management involvement } \\
\hline 1 & Light & BIM application on up to $15 \%$ of their projects & {$[20,21,26]$} \\
\hline 2 & Moderate & BIM application on 15 to $30 \%$ of their projects & {$[20,21,26]$} \\
\hline 3 & Heavy & BIM application on 31 to $60 \%$ of their projects. & {$[20,21,26]$} \\
\hline 4 & Very heavy & BIM application on above $60 \%$ of their projects. & {$[20,21,26]$} \\
\hline \multicolumn{4}{|c|}{ Organizational structure } \\
\hline 1 & Basic & BIM manager $\rightarrow$ Model authors & {$[78,86]$} \\
\hline 2 & Moderate & BIM manager $\rightarrow$ BIM coordinator $\rightarrow$ Model authors & {$[78,86]$} \\
\hline 3 & Mature & $\begin{aligned} \text { BIM manager } \rightarrow \text { BIM coordinator } \rightarrow \text { Task team managers } \\
\rightarrow \text { Model authors }\end{aligned}$ & {$[78,86]$} \\
\hline 4 & Seasoned & $\begin{array}{c}\text { BIM manager } \rightarrow \text { Information manager } \rightarrow \text { BIM coordinator } \rightarrow \text { Task team } \\
\text { managers } \rightarrow \text { Model authors }\end{array}$ & {$[78,86]$} \\
\hline \multicolumn{4}{|c|}{ Experience level within the organization } \\
\hline \multicolumn{4}{|c|}{$\begin{array}{l}\text { Years of using BIM: the percentage of BIM users within the target group who have used BIM } \\
\text { for more than five years }\end{array}$} \\
\hline 1 & Limited & $0-25 \%$ & {$[12,20,21,24]$} \\
\hline 2 & Moderate & $26-50 \%$ & {$[12,20,21,24]$} \\
\hline 3 & Fairly good & $51-75 \%$ & {$[12,20,21,24]$} \\
\hline 4 & Good & $76-100 \%$ & {$[12,20,21,24]$} \\
\hline \multicolumn{4}{|c|}{ Government supportive initiatives } \\
\hline 1 & Zero role & Government does not play any role in supporting the application of BIM. & {$[36,38,87]$} \\
\hline 2 & General role & $\begin{array}{l}\text { Government takes full advantage of their administrative functions and } \\
\text { actively participate in BIM promotion process. }\end{array}$ & {$[36,38,87]$} \\
\hline 3 & Guiding role & $\begin{array}{l}\text { Government has been supporting the application of BIM through } \\
\text { incentive policies. }\end{array}$ & {$[36,38,87]$} \\
\hline 4 & Leading role & $\begin{array}{l}\text { Government has been supporting the application of BIM through } \\
\text { compulsory policies. }\end{array}$ & {$[36,38,87]$} \\
\hline \multicolumn{4}{|c|}{ BIM vision } \\
\hline 1 & Beginner & A Basic BIM vision has been established. & {$[35,58,90]$} \\
\hline 2 & Moderate & To implement BIM at level 1. & {$[35,58,90]$} \\
\hline 3 & Advanced & To implement BIM at level 2. & {$[35,58,90]$} \\
\hline 4 & Expert & To implement BIM at level 3. & {$[35,58,90]$} \\
\hline \multicolumn{4}{|c|}{ Company size } \\
\hline 1 & Micro & 1-4 employees. & {$[12,36,37,39,50]$} \\
\hline 2 & Small & 5-19 employees. & {$[12,36,37,39,50]$} \\
\hline 3 & Medium & 20-199 employees. & {$[12,36,37,39,50]$} \\
\hline 4 & Large & More than 200 employees. & {$[12,36,37,39,50]$} \\
\hline
\end{tabular}

\subsubsection{Size of the Organization}

The literature observes that construction companies are usually categorized as Micro, Small, Medium, and Large, mainly based on their number of employees [35,37]. The literature suggests that larger organizations are better positioned to implement BIM and standardize their business process to optimize it due to a larger number of resources and experience available with them $[39,42]$. There is also some evidence suggesting that small and 
medium-sized organizations lag behind BIM implementation [40,65]. Considering these facts, four levels for measuring CSF of an organization's size were micro, small, medium, and large, where micro-organizations are at the lower level and large organizations at the highest level, as presented in Table 5.

\section{Results and Discussion}

For validating the developed indexes from field experts, the main survey of this paper was conducted globally to enhance representativeness and reliability. The participants of this survey were BIM experts having a BIM implementation experience of more than three years. An online questionnaire developed in Google Forms ${ }^{\circledR}$ was sent to experts through LinkedIn ${ }^{\circledR}$ and other professional networks. The survey was conducted between August 2020 and March 2021. The questionnaire consisted of two major sections: (i) the demographics and professional information of respondents and (ii) two questions for each developed index. The first question was related to the assessment of levels for respective indexes on a five-point Likert scale. In comparison, the second question was related to suggestions for improvement of these indexes.

Out of 250 questionnaires sent to a global target audience, a total of 99 responses were collected from 26 different countries, giving a response rate of $39.6 \%$. This sample size was considered sufficient according to statistics provided by Dillman et al. [92] and Gerges et al. [93]. These responses were collected from a range of experienced BIM professionals, as presented in Table 6. It is apparent from Table 6 that most of the respondents were BIM managers (38\%) and BIM specialists (25\%), with $66 \%$ of the respondents having more than five years of BIM experience. The respondents were mainly working with consultants $(65 \%)$, general contractors $(16 \%)$, subcontractors $(7 \%)$, and clients $(4 \%)$. Moreover, other respondents $(8 \%)$ were representing academic institutions, suppliers, and developers. The majority of the respondents $(77 \%)$ belonged to organizations with more than three years of experience with BIM, enhancing the maturity of the gathered data.

Table 6. Demographics of Respondents.

\begin{tabular}{|c|c|c|}
\hline Profile & Frequency & Percentage $(\%)$ \\
\hline \multicolumn{3}{|c|}{ Role } \\
\hline BIM manager & 29 & 38 \\
\hline BIM specialist & 19 & 25 \\
\hline BIM coordinator & 10 & 13 \\
\hline Others & 18 & 24 \\
\hline \multicolumn{3}{|c|}{ Type of organization } \\
\hline Consultant & 50 & 65 \\
\hline General contractor & 12 & 16 \\
\hline Sub contactor & 5 & 7 \\
\hline Client & 3 & 4 \\
\hline Other & 6 & 8 \\
\hline \multicolumn{3}{|c|}{ Years of BIM experience } \\
\hline 0 to 5 & 26 & 34 \\
\hline 6 to 10 & 34 & 45 \\
\hline 11 to 15 & 11 & 14 \\
\hline Above 15 & 5 & 7 \\
\hline \multicolumn{3}{|c|}{ Years of organization BIM experience } \\
\hline Less than 1 & 4 & 5 \\
\hline 1 to 3 & 14 & 18 \\
\hline 4 to 5 & 21 & 28 \\
\hline 6 to 10 & 21 & 28 \\
\hline Above 10 & 16 & 21 \\
\hline
\end{tabular}

The next step was the analysis of the gathered data. Cronbach's alpha test was applied to measure the internal consistency of the data. The results show the inter-correlation scores of 0.94 , which implies the data to be highly reliable. For ease of analysis, results were classified into three categories, i.e., agree, neutral, and disagree. This was carried 
out by merging the five-point Likert-scale categories of strongly agree and agree into a singular category, i.e., agree, and a similar approach was followed to merge the categories of disagreement. Table 7 shows the results for each level of the defined index. All the levels fall in the agreement category except for the last two levels of one index, i.e., experience level within the organization. The reason for this is the criticism by a majority of respondents. The respondents believe that no organization can fulfill the criteria in levels 3 and 4 of this index as BIM is a relatively new technology, and there are no organizations with $100 \%$ of employees with more than five years of BIM experience. Rather, there are few BIM experts in the majority of the organization. Thus, this scale warranted revision by reducing the number of years of the required experience.

Table 7. Analysis of results.

\begin{tabular}{|c|c|c|c|c|c|c|}
\hline Index & Sr. & Level Type & Agree & Neutral & Disagree & Category \\
\hline \multirow{4}{*}{ Training of employees } & 1 & Entry & 72 & 17 & 10 & Agree \\
\hline & 2 & Foundational & 74 & 13 & 12 & Agree \\
\hline & 3 & Intermediate & 76 & 18 & 5 & Agree \\
\hline & 4 & Advanced & 68 & 19 & 12 & Agree \\
\hline \multirow{4}{*}{ BIM expertise } & 1 & Beginner & 49 & 33 & 17 & Agree \\
\hline & 2 & Moderate & 53 & 30 & 16 & Agree \\
\hline & 3 & Advanced & 51 & 26 & 22 & Agree \\
\hline & 4 & Expert & 47 & 24 & 28 & Agree \\
\hline \multirow{4}{*}{ Experience level within the organization } & 1 & Limited & 54 & 22 & 23 & Agree \\
\hline & 2 & Moderate & 37 & 39 & 23 & Agree \\
\hline & 3 & Fairly Good & 37 & 24 & 38 & Disagree \\
\hline & 4 & Good & 36 & 20 & 43 & Disagree \\
\hline \multirow{4}{*}{ Willingness to change } & 1 & Laggards & 42 & 29 & 28 & Agree \\
\hline & 2 & Late Majority & 44 & 26 & 29 & Agree \\
\hline & 3 & Early Majority & 41 & 29 & 29 & Agree \\
\hline & 4 & Early Adopters & 55 & 26 & 18 & Agree \\
\hline \multirow{4}{*}{ Awareness level about BIM benefits } & 1 & Consideration & 60 & 27 & 12 & Agree \\
\hline & 2 & Involvement & 67 & 21 & 11 & Agree \\
\hline & 3 & Understanding & 69 & 25 & 5 & Agree \\
\hline & 4 & Valuing & 68 & 24 & 7 & Agree \\
\hline \multirow{4}{*}{ Top management involvement } & 1 & Light & 46 & 21 & 32 & Agree \\
\hline & 2 & Moderate & 46 & 26 & 27 & Agree \\
\hline & 3 & Heavy & 53 & 25 & 21 & Agree \\
\hline & 4 & Very Heavy & 65 & 14 & 20 & Agree \\
\hline \multirow{4}{*}{ Company size } & 1 & Micro & 43 & 14 & 42 & Agree \\
\hline & 2 & Small & 49 & 18 & 32 & Agree \\
\hline & 3 & Medium & 61 & 15 & 23 & Agree \\
\hline & 4 & Large & 62 & 12 & 25 & Agree \\
\hline \multirow{4}{*}{ Government supportive initiatives } & 1 & Not involved & 44 & 21 & 34 & Agree \\
\hline & 2 & General role & 37 & 27 & 35 & Agree \\
\hline & 3 & Guiding role & 38 & 26 & 35 & Agree \\
\hline & 4 & Leading role & 44 & 23 & 32 & Agree \\
\hline \multirow{4}{*}{ BIM vision } & 1 & Beginner & 60 & 25 & 14 & Agree \\
\hline & 2 & Moderate & 62 & 25 & 12 & Agree \\
\hline & 3 & Advanced & 69 & 19 & 11 & Agree \\
\hline & 4 & Expert & 66 & 15 & 18 & Agree \\
\hline \multirow{4}{*}{ Organizational structure } & 1 & Beginner & 44 & 27 & 28 & Agree \\
\hline & 2 & Moderate & 54 & 29 & 16 & Agree \\
\hline & 3 & Mature & 57 & 22 & 20 & Agree \\
\hline & 4 & Seasoned & 52 & 23 & 24 & Agree \\
\hline
\end{tabular}

The suggestions provided by the respondents were analyzed carefully, wherein the main proposition relates to the need to address the experience level within the organization. To address the obtained suggestions, three BIM experts having BIM experience of more than five years were interviewed. The BIM experts suggested that the index needs modification 
to measure BIM implementation on a smaller scale. In light of suggestions from respondents of the main survey and interviews from BIM experts, the years of using BIM were reduced from five to three to measure BIM implementation at an organizational level since BIM is a new technology and to gain experience with time [93]. Hence, the revised levels of limited experience, moderate experience, fairly good experience, and good experience were based on the percentage of BIM users within the target group who used BIM for more than three years instead of previously set five years.

\subsection{BIMp-Chart Development}

A decagon shape, as shown in Figure 2a, is anticipated for the visualization of BIMpChart. As illustrated in Figure 2b, all ten indexes are placed at the corners of a decagon. The decagon consists of four levels, with the center denoting $0 \%$, whereas the corners designating $100 \%$ implementation (fourth level) of a respective index, making each level $25 \%$ weightage. After identifying the levels of all the ten individual indexes for an organization, respective points are to be marked on a decagon for each index. The obtained points will be connected through a straight line, resulting in an irregular closed shape. The overall BIM implementation level can be represented by calculating the formed shape area within a decagon referred to as the BIMp-value.

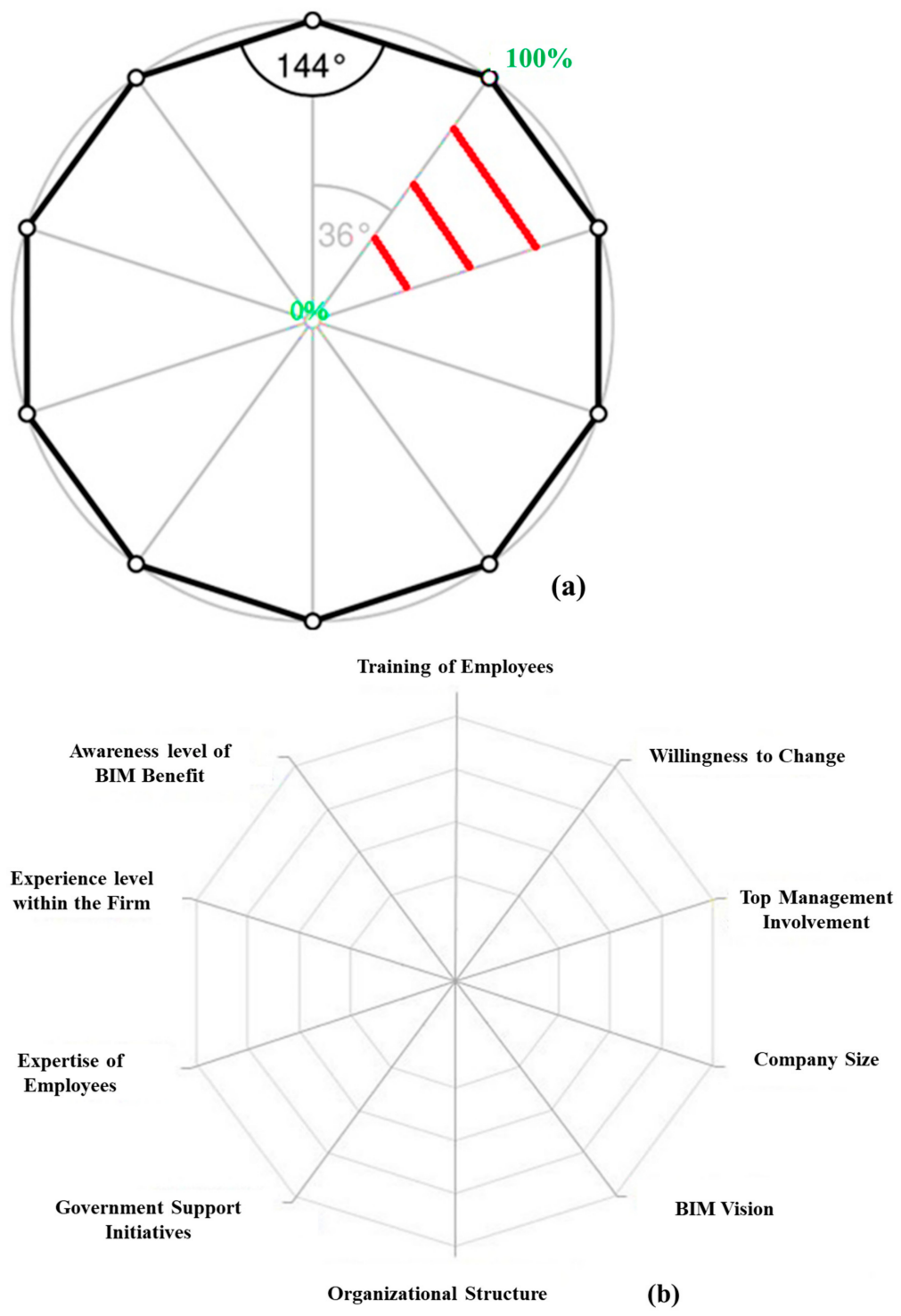

Figure 2. Visualization of proposed BIMp-Chart (a) decagon repesenting area through levels, (b) 10 indexes placed among vertices. 
The maximum BIMp-value that an organization can obtain is 294 by calculating the decagon area envisaged by Jung and Lee [20], as shown in Figure 3. Depending on the BIM implementation status within the organizations, different shapes and values can be obtained. The obtained shapes can help highlight the areas that need improvements, whereas the obtained values can become useful in comparing the overall results either with previous records or other organizations.

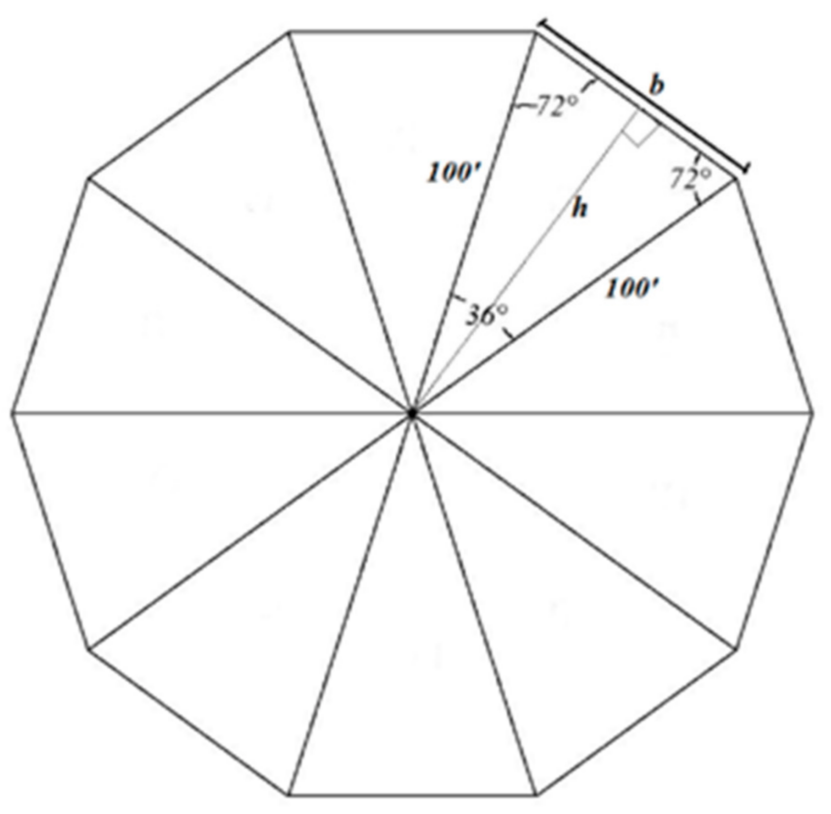

$$
\begin{aligned}
& h=\sin \left(72^{\circ}\right) \times 100=95.10 \\
& b=2 \times \sqrt{(100)^{2}-(h)^{2}}=61.8
\end{aligned}
$$

Area of Decagon $=10 \times\left(\frac{1}{2} b h\right)=294$

Figure 3. BIMp-chart value calculation.

\subsection{Application of BIMp-Chart}

To assess the applicability of the developed BIMp-Chart, representatives of four organizations from four different regions were interviewed. These include Qatar, Portugal, Egypt, and a multinational respondent. The demographics details of organizations are given in Table 8 .

Table 8. Demographics of representatives.

\begin{tabular}{ccccc}
\hline Demographics & Organization A & Organization B & Organization C & Organization D \\
\hline Designation of representative & BIM Manager & BIM Specialist & BIM Coordinator & BIM Manager \\
BIM experience of interviewee (in years) & 6 & 5 & 5 & 8 \\
Country of organization & Qatar & Portugal & Multinational & Egypt \\
Type of organization & Contractor & Consultant & Consultant & Contractor \\
Organization's BIM experience (in years) & 6 to 10 & 1 to 3 & 4 to 5 & 4 to 5 \\
\hline
\end{tabular}

All the indexes were discussed in detail with the representatives of organizations who were asked to select a singular level instance from each index according to their organization. Table 9 shows the datasets provided by representatives. Table highlights that the experience level within organizations and employees' expertise is on the low side due to BIM being a new technological development in the market. It is refreshing to note that three out of four organizations fell into the advanced category as the indexes of "BIM vision" and "training of employees" show a high level of top management involvement. All of this shows the interest and enthusiasm of organizations to progress and achieve high levels in BIM implementation. Four different shapes were obtained after incorporating the values into the proposed BIMp-Chart. Areas of these shapes were then calculated, and results were analyzed and compared. 
Table 9. Application of framework.

\begin{tabular}{|c|c|c|c|c|}
\hline Index & Organization A & Organization B & Organization $\mathrm{C}$ & Organization D \\
\hline Training of employees & Advanced & Advanced & Advanced & Intermediate \\
\hline Willingness to change & Early majority & Early adopters & Early adopters & Laggards \\
\hline Top management involvement & Heavy & Very heavy & Very heavy & Moderate \\
\hline Company size & Large & Small & Medium & Large \\
\hline BIM vision & Advanced & Advanced & Advanced & Moderate \\
\hline Organizational structure & Moderate & Basic & Seasoned & mature \\
\hline Government supportive initiatives & Guiding role & Zero role & Leading role & General role \\
\hline Expertise of employees & Moderate & Moderate & Expert & Moderate \\
\hline Experience level within the organization & Fairly good & Limited & Moderate & Moderate \\
\hline Awareness level about BIM benefits & Understanding & Understanding & Valuing & Involvement \\
\hline
\end{tabular}

BIMp value calculations for Organization $C$ are illustrated in Table 10. After inserting the data of Organization C, different types of triangles are achieved in the decagon. These include five triangles of type 1, two triangles of type 2, one triangle of type 3 , and two triangles of type 4 . The sum of areas of all triangles will indicate the total BIMp value for Organization C.

Table 10. BIMp-value calculation for Organization C.

\begin{tabular}{|c|c|c|c|c|c|c|}
\hline Type & Triangles & a & b & $c=\sqrt{a^{2}+b^{2}-2 a b\left(\cos 36^{\circ}\right)}$ & $s=\frac{a+b+c}{2}$ & $A=\sqrt{s \times(s-a) \times(s-b) \times(s-c)}$ \\
\hline 1 & 100 & 100 & 100 & 62 & 131 & 2941 \\
\hline 2 & 75 & 100 & 75 & 58 & 116 & 2100 \\
\hline 3 & 75 & 75 & 75 & 46 & 98 & 1641 \\
\hline 4 & 100 & 100 & 50 & 66 & 108 & 1450 \\
\hline \multicolumn{7}{|c|}{ Total Area $=[(5 \times 2941)+(2 \times 2941)+1641+(2 \times 1450)] / 100=234$} \\
\hline
\end{tabular}

Figure 4, developed using CAD software, represents the shapes obtained for organizations after incorporating index values. It can be observed that Organization A, with a BIMp-value of 160, needs more improvement in BIM expertise and organizational structure. For Organization B, the BIMp-value of 121 represents that few areas in Organization $B$ are extremely good but need improvement in the number of areas for high BIM implementation. Similarly, the area calculated for Organization C resulted in 234. This shows that the organization lacks in terms of experience level within the organization. Finally, the 
area calculated for Organization D came out to be 81. Although Organization D is a large organization, it is evident that it needs improvement in almost all the indexes for better BIM implementation within the organization. After observing all the four shapes and comparing the calculated areas, it is visually and quantitatively observed that Organization $\mathrm{C}$ has the highest BIM implementation level.

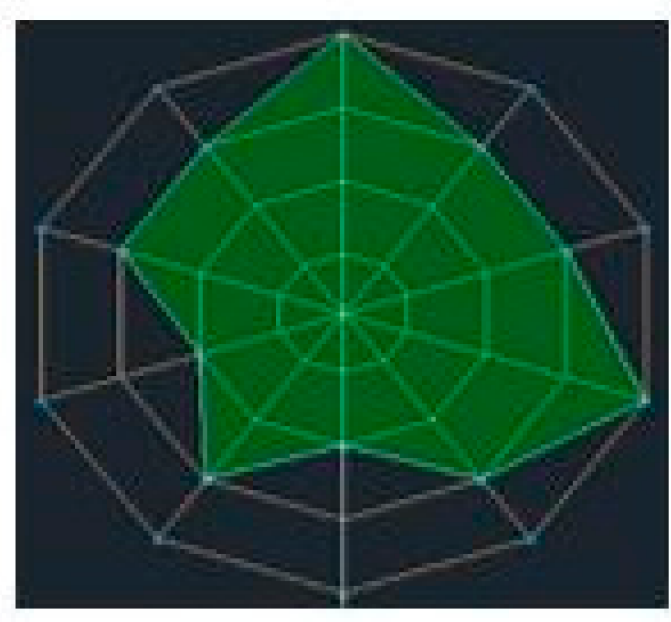

Organization A

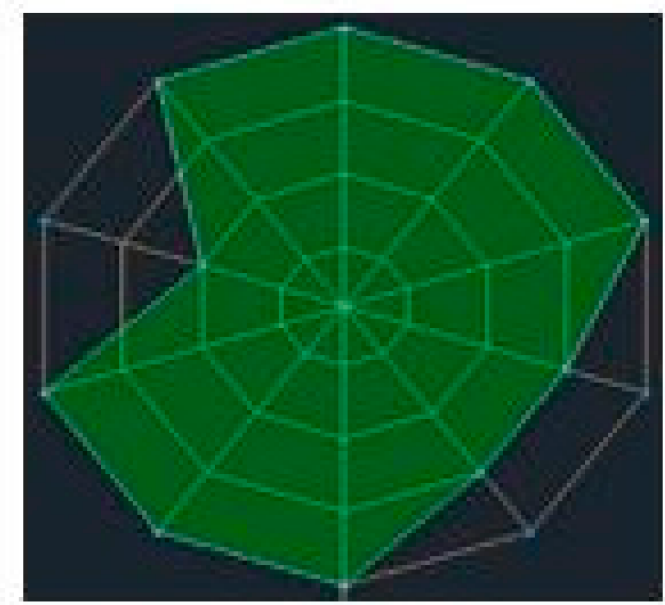

Organization C

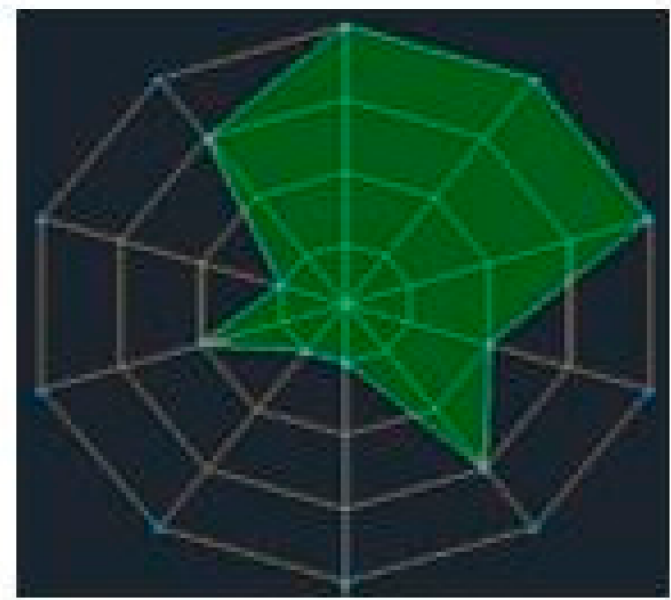

Organization B

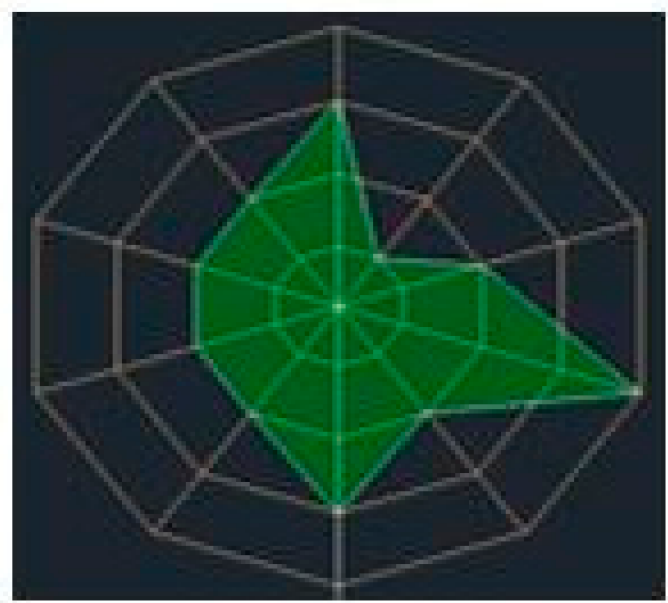

Organization D

Figure 4. Application of BIMp-Chart.

This application shows that the BIMp-Chart, on the one hand, can be very helpful for comparing BIM implementation levels of different organizations. The comparison between the organizations motivates the organization for even better BIM implementation to reach higher BIM implementation levels, ultimately achieving maximum benefits from BIM. On the other hand, it enables an organization to visually and quantitatively check their implementation level (where they are standing) by calculating the area obtained after incorporating their values for all the indexes. This will help the organizations find and emphasize the areas that need further improvements regarding BIM implementation, thereby making BIM applications effective and better. 


\section{Conclusions}

There has been an increasing interest in implementing BIM in the construction industry as it saves cost and time for project teams, elevates the quality of the project through improved coordination, planning, and lifecycle management of facilities, and enhances sustainability through energy and waste reduction using clash detection and energy simulations. However, BIM implementation is not free of challenges because of many factors. This study highlights the critical factors for the successful implementation of BIM, which will help better understand the fundamental elements of BIM implementation from a global perspective. The top ten factors are identified through a preliminary survey. The literature related to each significant factor was studied thoroughly to develop indexes comprising four levels to measure individual factors. The developed indexes were then validated by taking the perception of industry BIM experts through a global survey. A total of 99 experts from 26 different countries responded and validated all the indexes. The only disagreement was recorded in the last two levels of the index experience level within the organization since the majority believe that no organization would fall in levels 3 and 4 as there is a lower probability of employees having five years of BIM experience. This index was then revised (five years were reduced to three) by incorporating experts' suggestions.

Based on the developed indexes, the BIMp-Chart was proposed as a tool for the measurement of BIM implementation levels within construction organizations. Finally, the test cases were presented to show that the BIMp-Chart can provide BIM owners and researchers with a means to compare the different levels of BIM implementation visually and quantitatively in the construction organization. The BIMp-Chart will help the organizations to visualize BIM implementation levels through simple figures rapidly. It will also contribute to organizations comparing their current BIM performance with the previous ones and other organizations. The proposed BIMp-Chart acts as a decision support system for the construction organizations by identifying the areas that need improvements and providing goals to work out strategies for successfully enhancing BIM implementation. The BIMp-Chart also submissively motivates the construction organizations for BIM implementation, which subsequently contribute towards United Nation's sustainable development goals including inter-alia affordable and clean energy (SDG-7), industry, innovation, and infrastructure (SDG-9), responsible consumption and production (SDG-12) and climate action (SDG-13).

This study discussed literature and field data gathered from the survey; however, it is limited to a specific approach followed for retrieving the articles. The mechanism used to retrieve and shortlist the articles may not be exhaustive, and the same study repeated at a different time in a different context may yield different results. Future studies may incorporate detailed interviews from field practitioners to achieve even more realistic results. They can use the BIMp-Chart as a basic point to develop more advanced tools by incorporating the interdependencies of used CSFs on each other. Further, the study can be expanded to include more respondents from all global regions to develop holistic BIM implantation indexes.

Author Contributions: Conceptualization, Q.M. and A.R.N.; Data curation, Q.M.; Formal analysis, Q.M.; Investigation, Q.M.; Methodology, Q.M., A.R.N., M.J.T., F.U., K.I.A.K. and M.U.H.; Project administration, Q.M. and A.R.N.; Resources, Q.M., R.M. and F.U.; Supervision, A.R.N.; Validation, Q.M.; Visualization, Q.M.; Writing—original draft, Q.M.; Writing—review and editing, A.R.N., M.J.T., R.M. and F.U. All authors have read and agreed to the published version of the manuscript.

Funding: This research received no external funding.

Institutional Review Board Statement: Not applicable.

Informed Consent Statement: Informed consent was obtained from all respondents involved in the study.

Data Availability Statement: Not applicable.

Conflicts of Interest: The authors declare no conflict of interest. 


\section{References}

1. Abubakar, M.; Ibrahim, Y.M.; Kado, D.; Bala, K. Contractors' Perception of the Factors Affecting Building Information Modelling (BIM) Adoption in the Nigerian Construction Industry. In Computing in Civil and Building Engineering (2014); American Society of Civil Engineers (ASCE): Orlando, FL, USA, 2014; pp. 167-178.

2. Ullah, F.; Al-Turjman, F. A conceptual framework for blockchain smart contract adoption to manage real estate deals in smart cities. Neural Comput. Appl. 2021, 1-22. [CrossRef]

3. Ahuja, R.; Sawhney, A.; Jain, M.; Arif, M.; Rakshit, S. Factors influencing BIM adoption in emerging markets-The case of India. Int. J. Constr. Manag. 2020, 20, 65-76. [CrossRef]

4. Du, Y.; Zhou, H.; Yuan, Y.; Xue, H. Exploring the Moral Hazard Evolutionary Mechanism for BIM Implementation in an Integrated Project Team. Sustainability 2019, 11, 5719. [CrossRef]

5. Azhar, S.; Nadeem, A.; Mok, J.Y.; Leung, B.H. Building Information Modeling (BIM): A new paradigm for visual interactive modeling and simulation for construction projects. Proc. First Int. Conf. Constr. Dev. Ctries 2008, 1, 435-446.

6. Qayyum, S.; Ullah, F.; Al-Turjman, F.; Mojtahedi, M. Managing smart cities through six sigma DMADICV method: A review-based conceptual framework. Sustain. Cities Soc. 2021, 72, 103022. [CrossRef]

7. Ullah, F.; Sepasgozar, S.M.; Thaheem, M.J.; Al-Turjman, F. Barriers to the digitalisation and innovation of Australian Smart Real Estate: A managerial perspective on the technology non-adoption. Environ. Technol. Innov. 2021, 22, 101527. [CrossRef]

8. Jin, R.; Hancock, C.; Tang, L.; Chen, C.; Wanatowski, D.; Yang, L. Empirical study of BIM implementation-based perceptions among Chinese practitioners. J. Manag. Eng. 2017, 33, 04017025. [CrossRef]

9. Azhar, S.; Brown, J. BIM for Sustainability Analyses. Int. J. Constr. Educ. Res. 2009, 5, 276-292. [CrossRef]

10. Jin, R.; Tang, L.; Fan, K. Investigation into the current stage of BIM application in China's AEC industries. Build. Inf. Model. (BIM) Des. Constr. Oper. 2015, 149, 493-503. [CrossRef]

11. Smith, P. BIM implementation-global strategies. Procedia Eng. 2014, 85, 482-492. [CrossRef]

12. McGraw-Hill Construction. The business value of BIM in North America: Multi-year trend analysis and user ratings (2007-2012). In Smart Market Report; 2012. Available online: https://damassets.autodesk.net/content/dam/autodesk/www/solutions/ building-information-modeling/bim-value/mhc-business-value-of-bim-in-north-america.pdf (accessed on 15 August 2021).

13. Georgiadou, M.C. An overview of benefits and challenges of building information modelling (BIM) adoption in UK residential projects. Constr. Innov. 2019, 19, 298-320. [CrossRef]

14. Bhatti, I.A.; Abdullah, A.H.; Nagapan, S.; Bhatti, N.B.; Sohu, S.; Jhatial, A.A. Implementation of Building Information Modeling (BIM) in Pakistan Construction Industry. Eng. Technol. Appl. Sci. Res. 2018, 8, 3199-3202. [CrossRef]

15. Yan, H.; Demian, P. Benefits and barriers of building information modelling. In Proceedings of the 12th International Conference on Computing in Civil and Building Engineering (ICCCBE XII) \& 2008 International Conference on Information Technology in Construction (INCITE 2008), Beijing, China, 16-18 October 2008.

16. Arayici, Y.; Coates, S.; Koskela, L.; Kagioglou, M.; Usher, C.; O’Reilly, K. BIM adoption and implementation for architectural practices. Struct. Surv. 2011, 29, 7-25. [CrossRef]

17. Zhabrinna; Davies, R.J.; Pratama, M.M.A.; Yusuf, M. Proceedings of the MATEC Web of Conferences, 4th International Conference on Rehabilitation and Maintenance in Civil Engineering, Solo Baru, Indonesia, 11-12 July 2018; EDP Sciences: Solo, Central Java, Indonesia, 2018; Volume 195, p. 06003.

18. Yuan, H.; Yang, Y.; Xue, X. Promoting Owners' BIM Adoption Behaviors to Achieve Sustainable Project Management. Sustainability 2019, 11, 3905. [CrossRef]

19. Aibinu, A.A.; Papadonikolaki, E. Conceptualizing and operationalizing team task interdependences: BIM implementation assessment using effort distribution analytics. Constr. Manag. Econ. 2019, 38, 420-446. [CrossRef]

20. Jung, W.; Lee, G. Slim BIM Charts for Rapidly Visualizing and Quantifying Levels of BIM Adoption and Implementation. J. Comput. Civ. Eng. 2016, 30, 04015072. [CrossRef]

21. McGraw-Hill Construction. Building Information Modeling: Transforming Design and Construction to Achieve Greater Industry Productivity. 2008, pp. 5-7. Available online: http://images.autodesk.com/latin_am_main/files/mcgraw-hill_construction_ bim_smartmarket_report_december_2008.pdf (accessed on 15 August 2021).

22. Rogers, E.M. Diffusion of Innovations (1983); Free Press: New York, NY, USA, 1983.

23. Fenn, J.; Raskino, M. Mastering the Hype Cycle: How to Choose the Right Innovation at the Right Time; Harvard Business Press: Boston, MA, USA, 2008

24. Jung, W.; Lee, G. The status of BIM adoption on six continents. Int. J. Civil. Environ. Eng. 2015, 9, 512-516.

25. McCuen, T.L.; Suermann, P.C.; Krogulecki, M.J. Evaluating Award-Winning BIM Projects Using the National Building Information Model Standard Capability Maturity Model. J. Manag. Eng. 2012, 28, 224-230. [CrossRef]

26. Van Berlo, L.; Dijkmans, T.; Hendriks, H.; Spekkink, D.; Pel, W. BIM QuickScan: Benchmark of BIM performance in the Netherlands. In Proceedings of the CIB W78 2012: 29th International Conference, Beirut, Lebanon, 17-19 October 2012.

27. Al-Ashmori, Y.Y.; Othman, I.; Rahmawati, Y.; Amran, Y.H.M.; Sabah, S.H.A.; Rafindadi, A.D.; Mikić, M. BIM benefits and its influence on the BIM implementation in Malaysia. AIN Shams Eng. J. 2020, 11, 1013-1019. [CrossRef]

28. Azeem, M.; Ullah, F.; Thaheem, M.J.; Qayyum, S. Competitiveness in the construction industry: A contractor's perspective on barriers to improving the construction industry performance. J. Constr. Eng. Manag. Innov. 2020, 3, 193-219. [CrossRef] 
29. Chan, C.T. Barriers of implementing BIM in construction industry from the designers' perspective: A Hong Kong experience. J. Syst. Manag. Sci. 2014, 4, 24-40.

30. Ullah, F.; Sepasgozar, S.M.E. Key Factors Influencing Purchase or Rent Decisions in Smart Real Estate Investments: A System Dynamics Approach Using Online Forum Thread Data. Sustainability 2020, 12, 4382. [CrossRef]

31. Ullah, F.; Sepasgozer, S.; Tahmasebinia, F.; Sepasgozar, S.M.E.; Davis, S. Examining the impact of students' attendance, sketching, visualization, and tutors experience on students' performance: A case of building structures course in construction management. Constr. Econ. Build. 2020, 20, 3. [CrossRef]

32. Ullah, F.; Qayyum, S.; Thaheem, M.J.; Al-Turjman, F.; Sepasgozar, S.M. Risk management in sustainable smart cities governance: A TOE framework. Technol. Forecast. Soc. Chang. 2021, 167, 120743. [CrossRef]

33. Gholizadeh, P.; Esmaeili, B.; Goodrum, P. Diffusion of Building Information Modeling Functions in the Construction Industry. J. Manag. Eng. 2018, 34, 04017060. [CrossRef]

34. Liu, S.; Xie, B.; Tivendale, L.; Liu, C. Critical Barriers to BIM Implementation in the AEC Industry. Int. J. Mark. Stud. 2015, 7, 162. [CrossRef]

35. Latiffi, A.A.; Mohd, S.; Kasim, N.; Fathi, M.S. Building information modeling (BIM) application in Malaysian construction industry. Int. J. Constr. Eng. Manag. 2013, 2,1-6.

36. Ozorhon, B.; Karahan, U. Critical Success Factors of Building Information Modeling Implementation. J. Manag. Eng. 2017, 33, 04016054. [CrossRef]

37. Hosseini, M.R.; Pärn, E.A.; Edwards, D.J.; Papadonikolaki, E.; Oraee, M. Roadmap to Mature BIM Use in Australian SMEs: Competitive Dynamics Perspective. J. Manag. Eng. 2018, 34, 05018008. [CrossRef]

38. Zahrizan, Z.; Ali, N.M.; Haron, A.T.; Marshall-Ponting, A.; Hamid, Z. Exploring the adoption of Building Information Modelling (BIM) in the Malaysian construction industry: A qualitative approach. Int. J. Res. Eng. Technol. 2013, 2, 384-395.

39. Liao, L.; Teo, E.A.L.; Chang, R.; Li, L. Investigating Critical Non-Value Adding Activities and Their Resulting Wastes in BIM-Based Project Delivery. Sustainability 2020, 12, 355. [CrossRef]

40. Papadonikolaki, E. Loosely Coupled Systems of Innovation: Aligning BIM Adoption with Implementation in Dutch Construction. J. Manag. Eng. 2018, 34, 05018009. [CrossRef]

41. Liao, L.; Teo, E.A.L. Organizational Change Perspective on People Management in BIM Implementation in Building Projects. J. Manag. Eng. 2018, 34, 04018008. [CrossRef]

42. Liao, L.; Teo, E.A.L. Managing critical drivers for building information modelling implementation in the Singapore construction industry: An organizational change perspective. Int. J. Constr. Manag. 2019, 19, 240-256. [CrossRef]

43. Ghaffarianhoseini, A.; Tookey, J.; Ghaffarianhoseini, A.; Naismith, N.; Azhar, S.; Efimova, O.; Raahemifar, K. Building Information Modelling (BIM) uptake: Clear benefits, understanding its implementation, risks and challenges. Renew. Sustain. Energy Rev. 2017, 75, 1046-1053. [CrossRef]

44. Xu, J.; Jin, R.; Piroozfar, P.; Wang, Y.; Kang, B.-G.; Ma, L.; Wanatowski, D.; Yang, T. Constructing a BIM Climate-Based Framework: Regional Case Study in China. J. Constr. Eng. Manag. 2018, 144, 04018105. [CrossRef]

45. Eastman, C.M.; Jeong, Y.-S.; Sacks, R.; Kaner, I. Exchange Model and Exchange Object Concepts for Implementation of National BIM Standards. J. Comput. Civ. Eng. 2010, 24, 25-34. [CrossRef]

46. Elmualim, A.; Gilder, J. BIM: Innovation in design management, influence and challenges of implementation. Arch. Eng. Des. Manag. 2013, 10, 183-199. [CrossRef]

47. Miettinen, R.; Paavola, S. Beyond the BIM utopia: Approaches to the development and implementation of building information modeling. Autom. Constr. 2014, 43, 84-91. [CrossRef]

48. Liao, L.; Teo, E.A.L. Critical success factors for enhancing the building information modelling implementation in building projects in Singapore. J. Civ. Eng. Manag. 2017, 23, 1029-1044. [CrossRef]

49. Ma, X.; Xiong, F.; Olawumi, T.O.; Dong, N.; Chan, A.P.C. Conceptual Framework and Roadmap Approach for Integrating BIM into Lifecycle Project Management. J. Manag. Eng. 2018, 34, 05018011. [CrossRef]

50. Lee, S.; Yu, J.-H.; Jeong, D. BIM Acceptance Model in Construction Organizations. J. Manag. Eng. 2015, 31, 04014048. [CrossRef]

51. Shang, Z.; Shen, Z. Critical Success Factors (CSFs) of BIM Implementation for Collaboration based on System Analysis. In Computing in Civil and Building Engineering (2014); American Society of Civil Engineers (ASCE): Orlando, FL, USA, 2014; pp. $1441-1448$.

52. Succar, B.; Sher, W.; Williams, A. Measuring BIM performance: Five metrics. Arch. Eng. Des. Manag. 2012, 8, 120-142. [CrossRef]

53. Lam, T.T.; Mahdjoubi, L.; Mason, J. A framework to assist in the analysis of risks and rewards of adopting BIM for SMEs in the UK. J. Civ. Eng. Manag. 2017, 23, 740-752. [CrossRef]

54. Memon, A.H.; Rahman, I.A.; Memon, I.; Azman, N.I.A. BIM in Malaysian Construction Industry: Status, Advantages, Barriers and Strategies to Enhance the Implementation Level. Res. J. Appl. Sci. Eng. Technol. 2014, 8, 606-614. [CrossRef]

55. Cao, D.; Li, H.; Wang, G.; Zhang, W. Linking the motivations and practices of design organizations to implement Building Information Modeling in construction projects: Empirical study in China. J. Manag. Eng. 2016, 32, 04016013. [CrossRef]

56. Lee, S.; Yu, J. Comparative Study of BIM Acceptance between Korea and the United States. J. Constr. Eng. Manag. 2015, 142, 05015016. [CrossRef]

57. Aibinu, A.A.; Venkatesh, S. Status of BIM Adoption and the BIM Experience of Cost Consultants in Australia. J. Prof. Issues Eng. Educ. Pr. 2014, 140, 04013021. [CrossRef] 
58. Forsythe, P. The Case for BIM Uptake among Small Construction Contracting Businesses. In Proceedings of the 31st International Symposium on Automation and Robotics in Construction and Mining (ISARC), Sydney, Australia, 9-11 July $2014 ;$ pp. $480-487$.

59. Eadie, R.; Browne, M.; Odeyinka, H.; McKeown, C.; McNiff, S. BIM implementation throughout the UK construction project lifecycle: An analysis. Autom. Constr. 2013, 36, 145-151. [CrossRef]

60. Das, M.; Tao, X.; Cheng, J.C. BIM security: A critical review and recommendations using encryption strategy and blockchain. Autom. Constr. 2021, 126, 103682. [CrossRef]

61. Poirier, E.; Staub-French, S.; Forgues, D. Embedded contexts of innovation. Constr. Innov. 2015, 15, 42-65. [CrossRef]

62. Xue, F.; Lu, W. A semantic differential transaction approach to minimizing information redundancy for BIM and blockchain integration. Autom. Constr. 2020, 118, 103270. [CrossRef]

63. Wang, L.; Huang, M.; Zhang, X.; Jin, R.; Yang, T. Review of BIM Adoption in the Higher Education of AEC Disciplines. J. Civ. Eng. Educ. 2020, 146, 06020001. [CrossRef]

64. Abu Awwad, K.; Shibani, A.; Ghostin, M. Exploring the critical success factors influencing BIM level 2 implementation in the UK construction industry: The case of SMEs. Int. J. Constr. Manag. 2020, 1-8. [CrossRef]

65. Arshad, M.F.; Thaheem, M.J.; Nasir, A.R.; Malik, M.S.A. Contractual Risks of Building Information Modeling: Toward a Standardized Legal Framework for Design-Bid-Build Projects. J. Constr. Eng. Manag. 2019, 145, 04019010. [CrossRef]

66. Pan, Y.; Zhang, L. BIM log mining: Learning and predicting design commands. Autom. Constr. 2020, 112, 103107. [CrossRef]

67. Pour Rahimian, F.; Seyedzadeh, S.; Oliver, S.; Rodriguez, S.; Dawood, N. On-demand monitoring of construction projects through a game-like hybrid application of BIM and machine learning. Autom. Constr. 2020, 110, 103012. [CrossRef]

68. Almuntaser, T.; Sanni-Anibire, M.O.; Hassanain, M.A. Adoption and implementation of BIM-Case study of a Saudi Arabian AEC firm. Int. J. Manag. Proj. Bus. 2018, 11, 608-624. [CrossRef]

69. Moreno, C.; Olbina, S.; Issa, R.R. BIM Use by Architecture, Engineering, and Construction (AEC) Industry in Educational Facility Projects. Adv. Civ. Eng. 2019, 2019, 1-19. [CrossRef]

70. Ullah, F.; Sepasgozar, S.M.; Thaheem, M.J.; Wang, C.C.; Imran, M. It's all about perceptions: A DEMATEL approach to exploring user perceptions of real estate online platforms. AIN Shams Eng. J. 2021. [CrossRef]

71. Chong, H.-Y.; Fan, S.-L.; Sutrisna, M.; Hsieh, S.-H.; Tsai, C.-M. Preliminary Contractual Framework for BIM-Enabled Projects. J. Constr. Eng. Manag. 2017, 143, 04017025. [CrossRef]

72. Babar, S.; Thaheem, M.J.; Ayub, B. Estimated Cost at Completion: Integrating Risk into Earned Value Management. J. Constr. Eng. Manag. 2017, 143, 04016104. [CrossRef]

73. Rasul, N.; Malik, M.S.A.; Bakhtawar, B.; Thaheem, M.J. Risk assessment of fast-track projects: A systems-based approach. Int. J. Constr. Manag. 2019, 1-16. [CrossRef]

74. Ahmad, Z.; Thaheem, M.J.; Maqsoom, A. Building information modeling as a risk transformer: An evolutionary insight into the project uncertainty. Autom. Constr. 2018, 92, 103-119. [CrossRef]

75. Amuda-Yusuf, G. Critical Success Factors for Building Information Modelling Implementation. Constr. Econ. Build. 2018, 18, 55-73. [CrossRef]

76. Vass, S.; Gustavsson, T.K. Challenges when implementing BIM for industry change. Constr. Manag. Econ. 2017, 35, 597-610. [CrossRef]

77. Khosrowshahi, F.; Arayici, Y. Roadmap for implementation of BIM in the UK construction industry. Eng. Constr. Arch. Manag. 2012, 19, 610-635. [CrossRef]

78. Baldwin, M. The BIM-Manager: A Practical Guide for BIM Project Management; Beuth Verlag GmbH: Berlin, Germany, 2019.

79. ISO. Organization and Digitization of Information about Buildings and Civil Engineering Works, Including Building Information Modelling (BIM); BSI: London, UK, 2018. Available online: https:/ /www.iso.org/standard/68078.html (accessed on 15 August 2021).

80. Mohammad, W.N.S.W.; Abdullah, M.R.; Ismail, S.; Takim, R. Overview of Building Information Modelling (BIM) adoption factors for construction organisations. In Proceedings of the IOP Conference Series: Earth and Environmental Science, Langkawi, Malaysia, 4-5 December 2017; Volume 140, p. 012107.

81. Joseph, J. Bim Titles and Job Descriptions: How Do They Fit in Your Organizational Structure. Autodesk University. 2011. Available online: https://pdf4pro.com/amp/cdn/bim-titles-and-job-descriptions-how-do-they-fit-in-your-5b2841.pdf (accessed on 15 August 2021).

82. McArthur, J.; Sun, X. Best practices for BIM Execution Plan development for a Public-Private Partnership Design-Build-FinanceOperate-Maintain project. Build. Inf. Model. (BIM) Des. Constr. Oper. 2015, 149, 119-130. [CrossRef]

83. NBS. Specification for Information Management for the Capital/Delivery Phase of Construction Projects using Building Information Modelling. 2013. Available online: https:/ / www.thenbs.com/PublicationIndex/documents / details?Pub=BSI\&DocId=3064 48 (accessed on 15 August 2021).

84. Kensek, K.M. Building Information Modeling; Routledge: Oxfordshire, England, UK, 2014.

85. Davies, K.; Wilkinson, S.; McMeel, D. A review of specialist role definitions in BIM guides and standards. J. Inf. Technol. Constr. 2017, 22, 185-203.

86. Mehran, D. Exploring the Adoption of BIM in the UAE Construction Industry for AEC Firms. Procedia Eng. 2016, 145, 1110-1118. [CrossRef]

87. Yaakob, M.; Wan, W.N.A.; Radzuan, K. Critical success factors to implementing building information modeling in Malaysia construction industry. Int. Rev. Manag. Mark. 2016, 6, 252-256. 
88. Giel, B.; Issa, R.R.A. Framework for Evaluating the BIM Competencies of Building Owners. In Computing in Civil and Building Engineering (2014); American Society of Civil Engineers (ASCE): Orlando, FL, USA, 2014; pp. 552-559.

89. Kogut, P. BIM vision in Poland. Int. Constr. Inf. Soc. 2015. Available online: https://icis.org/wp-content/uploads/2017/11/ ICIS2015-BIM-vision-in-Poland-P.Kogut_.pdf (accessed on 15 August 2021).

90. Rao, K.U.; Kishore, V. A review of technology diffusion models with special reference to renewable energy technologies. Renew. Sustain. Energy Rev. 2010, 14, 1070-1078. [CrossRef]

91. Enegbuma, W.I.; Ali, K.N. A preliminary critical success factor (CSFs) analysis of building information modelling (BIM) implementation in Malaysia. In Proceedings of the Asian Conference on Real Estate Sustainable Growth, Management Challenges, Thistle Johor Bahru, Malaysia, 3-5 October 2011.

92. Dillman, D.A.; Smyth, J.D.; Christian, L.M. Internet, Phone, Mail, and Mixed-Mode Surveys: The Tailored Design Method; John Wiley \& Sons: Hoboken, NJ, USA, 2014.

93. Gerges, M.; Austin, S.; Mayouf, M.; Ahiakwo, O.; Jaeger, M.; Saad, A.; El Gohary, T. An investigation into the implementa-tion of Building Information Modeling in the Middle East. J. Inf. Technol. Constr. 2017, 22, 1-15. 